\title{
Assessment of integrated watershed health based on the natural environment, hydrology, water quality, and aquatic ecology
}

\author{
So Ra Ahn ${ }^{1}$ and Seong Joon Kim ${ }^{2}$ \\ ${ }^{1}$ Texas A\&M AgriLife Research Center at El Paso, Texas 79927, USA \\ ${ }^{2}$ Department of Civil, Environmental, and Plant Engineering, Konkuk University, Seoul 05029, South Korea \\ Correspondence to: Seong Joon Kim (kimsj@konkuk.ac.kr)
}

Received: 15 February 2017 - Discussion started: 24 February 2017

Revised: 8 August 2017 - Accepted: 2 October 2017 - Published: 14 November 2017

\begin{abstract}
Watershed health, including the natural environment, hydrology, water quality, and aquatic ecology, is assessed for the Han River basin $\left(34148 \mathrm{~km}^{2}\right)$ in South Korea by using the Soil and Water Assessment Tool (SWAT). The evaluation procedures follow those of the Healthy Watersheds Assessment by the U.S. Environmental Protection Agency (EPA). Six components of the watershed landscape are examined to evaluate the watershed health (basin natural capacity): stream geomorphology, hydrology, water quality, aquatic habitat condition, and biological condition. In particular, the SWAT is applied to the study basin for the hydrology and water-quality components, including 237 subwatersheds (within a standard watershed on the Korea Hydrologic Unit Map) along with three multipurpose dams, one hydroelectric dam, and three multifunction weirs. The SWAT is calibrated (2005-2009) and validated (2010-2014) by using each dam and weir operation, the flux-tower evapotranspiration, the time-domain reflectometry (TDR) soil moisture, and groundwater-level data for the hydrology assessment, and by using sediment, total phosphorus, and total nitrogen data for the water-quality assessment. The water balance, which considers the surface-groundwater interactions and variations in the stream-water quality, is quantified according to the sub-watershed-scale relationship between the watershed hydrologic cycle and stream-water quality. We assess the integrated watershed health according to the U.S. EPA evaluation process based on the vulnerability levels of the natural environment, water resources, water quality, and ecosystem components. The results indicate that the watershed's health declined during the most recent 10 -year period of 2005-2014, as indicated by the worse results for the surface process metric and soil water dynamics compared
\end{abstract}

to those of the 1995-2004 period. The integrated watershed health tended to decrease farther downstream within the watershed.

\section{Introduction}

Watershed management can be defined as the integrated and iterative decision process that is applied to maintain the sustainability of resources through the balanced use and conservation of water quantity, land, vegetation, and other natural resources within the watershed. Rivers are a constituent element of watershed ecosystems that are of primary concern for watershed management; river discharge and water quality are key components of watershed ecosystems, and their interactions can be affected by land use and vegetation cover. The Han River basin in South Korea, with its large-scale water supply dams and weirs, is a rare case. Twenty-six years ago, the government initiated programs to restore the environmental and human health-related quality of the Han River basin. However, an integrated approach that considers the water supply, water-quality improvement, and natural-ecosystem maintenance and their interactions within the watershed has been lacking. A broader view of watershed ecosystems is essential to truly protect the chemical, physical, and biological integrity of our watersheds (U.S. EPA, 2012).

One of the key components of watershed-management strategies is to increase the protection of healthy waters, including healthy watersheds. A key component of watershed health is its ability to withstand, recover from, or adapt to disturbances, such as floods and droughts. A more complete understanding of the watershed-ecosystem components 
that affect watershed health is important to identify management actions to protect healthy watersheds. Without an integrated watershed-health-assessment system, any successes in restoring impaired waters will be limited and the many socioeconomic benefits of healthy watershed systems will be lost.

Generally, the assessment of the major components of watershed health must incorporate evaluations of the natural environment, hydrology, water quality, and aquatic ecology. A number of studies have recently assessed the potential for effective watershed management through an analysis of a variety of health indicators. Sanchez et al. (2015) characterized the relationships among in-stream health indicators (flow, sediment, and nutrient loads) by using the Soil and Water Assessment Tool (SWAT) and the socioeconomic measures of communities by using spatial-clustering techniques and confirmatory-factor analysis in the Saginaw River watershed in Michigan. Cook et al. (2015) examined these relationships in five watersheds along the Virginia-Kentucky border and explored the effects of both the water quality and habitat on benthic macro-invertebrates by using data from a 3-year field study and Virginia Stream Condition Index (VSCI) scores to evaluate site-specific environmental variables (land use, habitat metrics, and water-quality parameters). Tango and Batiuk (2016) analyzed the interactions that affect the watershed and bay-water-quality recovery responses to management actions and a range of health conditions and impairments by measuring the physical, chemical, and biological parameters in Chesapeake Bay.

The U.S. EPA has made considerable efforts to move towards integrated evaluations of watershed health. For example, the Virginia Watershed Integrity Model uses an integrated approach to evaluate the landscape condition and terrestrial habitat to identify ecologically important catchments across the landscape (Virginia Department of Conservation and Recreation, 2008). Minnesota's Watershed Assessment Tool uses hydrology, geomorphology, biology, connectivity, and water-quality data in an integrated context to evaluate the health of Minnesota's watersheds (Minnesota Department of Natural Resources, 2011). The Oregon Watershed Assessment addresses the landscape, habitat, biology, water quality, hydrology, and geomorphology through field assessments and follow-up analyses based on a classification and condition assessment of channel habitat types (Watershed Professionals Network, 1999). The California Watershed Assessment Manual evaluates the six essential ecological attributes of landscape status: hydrology/geomorphology, biotic condition, chemical/physical condition, natural disturbance regimes, and ecological condition (Shilling, 2007).

The regional water quantity and quality can be assessed through systematic modeling by using the SWAT hydrologic model (Arnold et al., 1998) because of its robust approach based on the soil water balance at the watershed scale. The SWAT model has been successfully applied to a number of river basins and is widely used to study the long-term ef- fects of hydrological (e.g., Sun and Cornish, 2005; Wan et al., 2013; Ahn et al., 2016; Karlsson et al., 2016; Sellami et al., 2016; Chung et al., 2017) and environmental (e.g., Eckhardt and Ulbrich, 2003; Rosenberg et al., 2003; Bouraoui et al., 2004; Chaplot, 2007; Mehdi et al., 2015; Zhou and $\mathrm{Li}, 2015$ ) changes. Thus, the use of this qualified watershed model is highly useful for assessments of continuous timeseries changes and spatial-distribution changes in watershed information.

However, most previous studies employed a fragmentary approach to investigate one or several environmental issues by using monitoring data for a limited period without assessing the various components (e.g., landscape, stream channels, hydrology, water quality, habitat, biological diversity). Thus, the methodology that is suggested in this study is essential to explore the integrated influence of large-scale watersheds with various watershed characteristics and assess the overall health of watersheds.

Therefore, the main objective of this study is to conduct a watershed-health-assessment analysis of the natural environment, hydrology, water quality, and aquatic ecology of the Han River basin (34 148 km²) in South Korea by using monitoring data and SWAT-modeling outputs. Detailed information regarding the framework is presented below.

\section{Materials and methods}

\subsection{Methodology for watershed-health assessment}

The foundation of watershed-health assessment is the compilation and summarization of watershed parameters based on the primary physical attributes of watershed conditions. According to the United States Environmental Protection Agency (U.S. EPA, 2012), six essential indicators are fundamental to the assessment of watershed health: (1) the landscape condition, (2) geomorphology, (3) hydrology, (4) water quality, (5) habitat, and (6) biological condition. A sub-index for each of the six components is developed from these indicators. The sub-index values are then aggregated into a single Watershed Health Index value for each watershed. This methodology can be used to assess the natural capacity of a watershed and its problems and draft possible solutions for effective watershed management. All sub-index and index values are relative (i.e., "healthier" vs. "not as healthy") rather than absolute (i.e., no "healthy vs. unhealthy" cutoff score is identified) and thus are meant for comparing the relative differences among watersheds rather than precisely defining healthy vs. unhealthy watersheds.

In this study, indicators for watershed-health assessment are selected based on the six essential components and methodology that were suggested by the U.S. EPA. All the indicators for watershed health are evaluated to match the situation in South Korea by using measurable data or watershed modeling results. In particular, the methodology is developed 


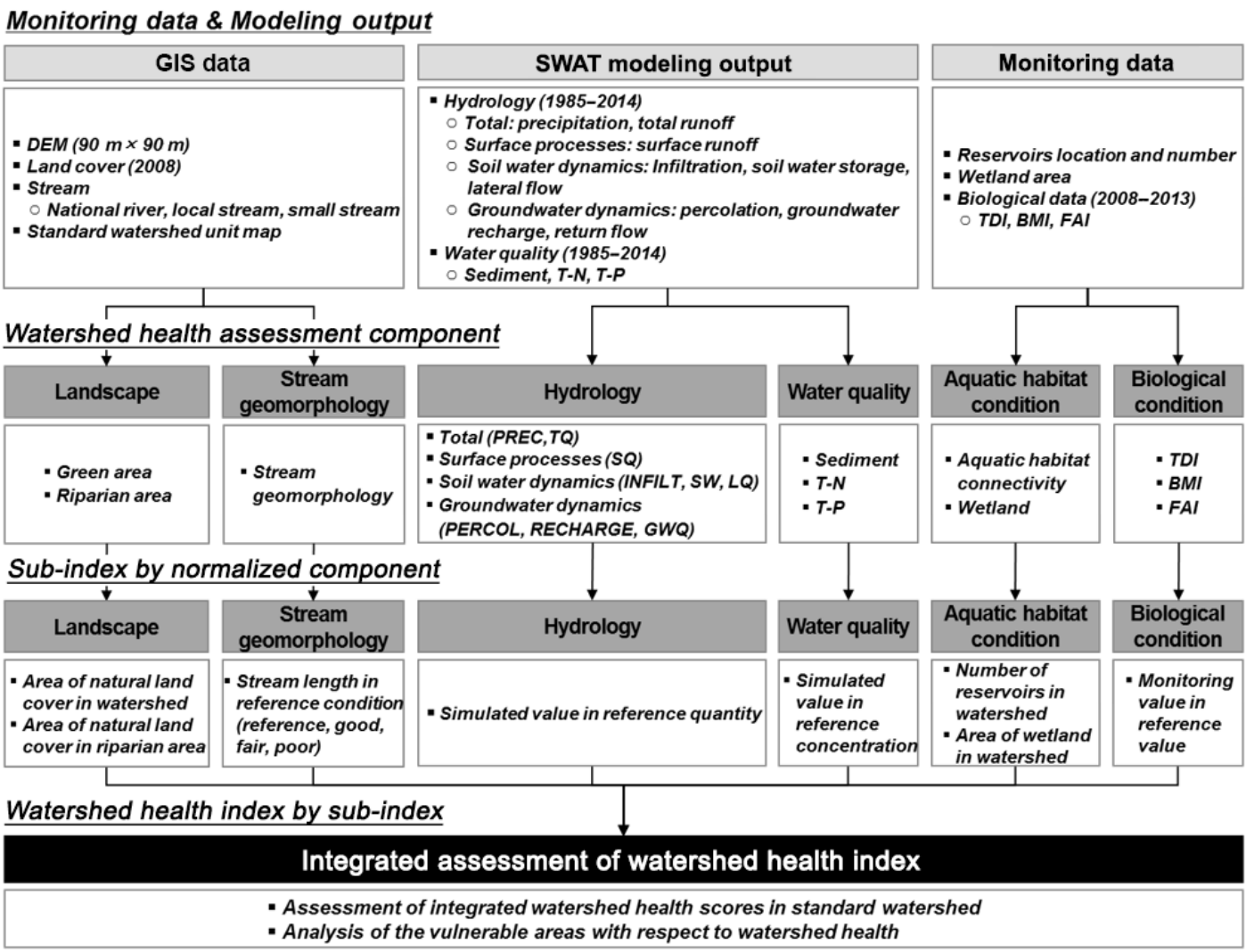

Figure 1. Flowchart of the study procedure for the watershed-health assessment.

to assess the effects of hydrology and water quality on watershed health to analyze the possible long-term changes in the watershed as simulated through a watershed-scale hydrological model, namely, the SWAT. According to existing research that assessed the long-term changes in the Han River basin, the changes in runoff from climate change in the Han River basin are expected to cause many changes to the future seasonal water volume, and water scarcity is predicted to increase in the long term (Jun et al., 2011; Kim et al., 2014). Urban land cover in the Han River basin is positively associated with increases in water pollution, which has increased for the majority of the monitoring stations (Chang, 2008). Healthy areas can be identified based on standard watersheds from the Korea Hydrologic Unit Map. The Korea Hydrologic Unit Map is a standard map that combines data from national organizations for water-resource development, planning, and management. These standard watersheds are the smallest hydrologic units that are designated by the Korean government. Figure 1 shows a flowchart of the modeling procedures. The specific objectives of this study are as follows.

Develop a method to reconstruct water quantity and quality time-series data of the basin by using the SWAT model. The reconstructed time series are used as water quantity and quality indicators and for sub-index development. Watershed-health assessment relies on the continuous flow of time-series information, so the SWAT model is established and calibrated to obtain flow records at ungauged hydrology and water-quality stations.

Establish a reference condition for each indicator to assess the sub-index by normalizing the following components: the landscape condition, geomorphology, hydrology, water quality, habitat, and biological condition.

Assign integrated watershed-health scores that combine multiple indicators to represent different attributes of healthy watersheds based on a standard watershed on the Korea Hydrologic Unit Map.

\subsection{Study area description}

The Han River basin $\left(34148 \mathrm{~km}^{2}\right)$ is one of the five major river basins in South Korea $\left(99720 \mathrm{~km}^{2}\right)$. This basin occupies approximately $31 \%$ of the country and falls within the latitude-longitude range from 36.03 to $38.55^{\circ} \mathrm{N}$ and from 126.24 to $129.02^{\circ} \mathrm{E}$, respectively (Fig. 2). The basin has three main rivers: the North Han River $\left(12969 \mathrm{~km}^{2}\right)$, the South Han River $\left(12894 \mathrm{~km}^{2}\right)$, and the Imjin River $\left(8285 \mathrm{~km}^{2}\right)$. The North and South Han rivers merge and then flow into the metropolitan city of Seoul, a city of 10 million residents. The water resources of the river basin must be sustainably managed because of the expanding water demand of 


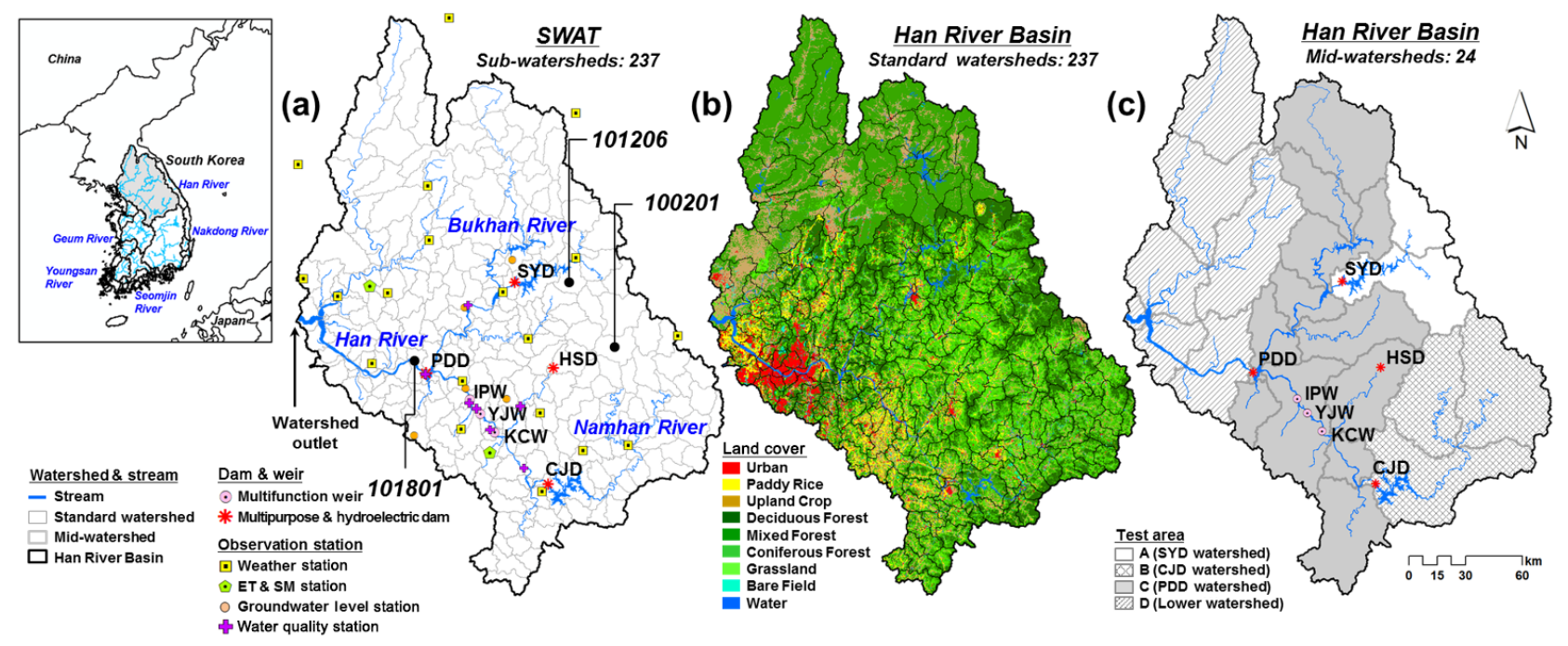

Figure 2. Locations of the (a) Han River basin's boundaries and gauging stations for the watershed (SWAT) modeling, (b) land-cover classification, and (c) test area.

the Seoul area, including its satellite cities (12 million individuals), and potential changes to water resources from climate change must be evaluated (Ahn and Kim, 2016). The dominant land use of the Han River basin is forest $(73 \%$, $25033 \mathrm{~km}^{2}$ ), followed by cultivated cropland in the lowland fertile areas $\left(5915 \mathrm{~km}^{2}\right)$, including rice paddy fields $(6 \%)$ and upland crops (12\%) (Fig. 2b). Over the 30 years of weather data from 1985 to 2014, the average annual precipitation was $1395 \mathrm{~mm}$ and the annual mean temperature was $11.5^{\circ} \mathrm{C}$. Figure $2 \mathrm{a}$ shows the study area and the 237 subwatersheds (within a standard watershed on the Korea Hydrologic Unit Map) that were delineated for the SWAT modeling and watershed-health assessment, and Fig. 2c shows the four test areas for a comparison of the watershed-health index scores.

\subsection{SWAT model description}

The SWAT model is a physically based, continuous, longterm, distributed parameter model that is designed to predict the effects of land-management practices on hydrology and water quality in agricultural watersheds under varying soil, land-use, and management conditions (Arnold et al., 1998). The SWAT model is based on the concept of hydrologic response units (HRUs), which are portions of a sub-basin with unique land-use, management, and soil attributes. The runoff, sediment, and nutrient loadings from each HRU are calculated separately based on the weather, soil properties, topography, vegetation, and land management and are then summed to determine the total loading from the sub-basin (Neitsch et al., 2002). A detailed description can be found in the Soil and Water Assessment Tool's user's manual and theoretical documentation (Neitsch et al., 2005).

\subsection{Data collection}

A summary of the datasets and associated organization sources, metrics, and measurement methods that were used in the assessment is provided in Table 1 . These data were used to calculate the health-assessment components for each of the six watersheds.

Geographic Information System (GIS) datasets were used for the landscape, stream geomorphology, and aquatic habitat assessment. The elevation data used the $90 \mathrm{~m}$ grid-size Shuttle Radar Topography Mission (SRTM) digital elevation model (DEM) that was supplied by the International Center for Tropical Agriculture (CIAT). The land-cover map for nine classes of land cover (coniferous forest, deciduous forest, mixed forest, paddy rice, upland crop, urban, grassland, bare field, and water) for 2008 was obtained from the Korea Ministry of Environment (KME). The stream map for national and local streams was obtained from the Ministry of Land, Infrastructure, and Transport (MOLIT) of South Korea. The information on the location and number of reservoirs for the Han River basin was obtained from the Korea Rural Community Corporation (KRC).

The SWAT-modeling outputs for a total of 237 subwatersheds for the Han River basin, including ungauged locations, were used for the hydrology and water-quality assessments. The monitoring data for the hydrology include only streamflow and do not include data for the water-balance components that are associated with surfacegroundwater interactions. The monitoring data for the water quality are not exhaustive. The period of the waterquality components of interest for this study, such as the sediments, total nitrogen (T-N), and total phosphorus (T-P), is not sufficient to analyze long-term changes. The continuous daily record of precipitation (PREC), total runoff (TQ), 
Table 1. Metrics and summary dataset that was used to assess the watershed health in the study watershed.

\begin{tabular}{|c|c|c|}
\hline Component (metric) & Measurement method & Dataset \\
\hline Landscape & & GIS data \\
\hline Green infrastructure metric & Percentage of the watershed that is occupied by natural land cover & Land cover $2008^{\mathrm{a}}$ \\
\hline Active river area metric & Percentage of natural land cover within the active river area & Land cover 2008, stream $^{\mathrm{b}}$ \\
\hline Geomorphology & & GIS data \\
\hline Stream geomorphology metric & Percentage of assessed stream length in the reference condition & SRTM DEM $(90 \times 90)^{\mathrm{c}}$, stream \\
\hline Hydrology & & SWAT modeling data (1985-2014) \\
\hline Total metric & Precipitation and total runoff storage ratio & PREC, TQ \\
\hline Surface processes metric & Surface runoff storage ratio & SQ \\
\hline Soil water dynamics metric & Infiltration, soil water, and lateral flow storage ratio & INFILT, SW, LQ \\
\hline Groundwater dynamics metric & Percolation, groundwater recharge, and return flow storage ratio & PERCOL, RECHARGE, GWQ \\
\hline Water quality & & SWAT modeling data (1985-2014) \\
\hline Water-quality metric & Percentage of the assessed value in the reference criteria & Sediment, T-N, T-P \\
\hline Aquatic habitat condition & & GIS data \\
\hline Habitat connectivity metric & Reservoir density (number of reservoirs per stream length) & Reservoir location map ${ }^{\mathrm{d}}$, stream \\
\hline Wetland metric & Percentage of the watershed that is occupied by wetlands & Land cover 2008 \\
\hline Biological condition & & Monitoring data $(2008-2013)^{\mathrm{e}}$ \\
\hline Biological metric & Percentage of the assessed score in the reference condition & TDI, BMI, FAI \\
\hline
\end{tabular}

Main data sources included ${ }^{\mathrm{a}}$ the Korea Ministry of Environment (KME); ${ }^{\mathrm{b}}$ the Ministry of Land, Infrastructure, and Transport (MOLIT) in South Korea; ${ }^{\mathrm{c}}$ the International Center for Tropical Agriculture (CIAT); ${ }^{\mathrm{d}}$ the Korea Rural Community Corporation (KRC); and ${ }^{\mathrm{e}}$ the Korea Ministry of Environment (KME) in South Korea (Ministry of Environment, 2013).

surface runoff (SQ), infiltration (INFILT), soil water storage (SW), lateral flow (LQ), percolation (PERCOL), groundwater recharge (RECHARGE), and return flow (GWQ) data for the hydrology metric and the record of sediment, T-N, and T-P for the water-quality metric were obtained from SWAT modeling for a 30-year period (1985-2014).

For the biological assessment, the monitoring data were obtained from the Korea Ministry of Environment (KME) in South Korea, which has been monitoring river ecological data for 360 monitoring stations in the Han River and its tributaries since 2008. Samples of trophic diatom communities (339 species), benthic macroinvertebrate communities (344 species), and fish communities (394 species) were collected from the monitoring stations in September and October of each year over a 6-year period (2008-2013), and the Trophic Diatom Index (TDI), Benthic Macroinvertebrate Index (BMI), and Fish Assessment Index (FAI) were calculated and classified by ranking the arithmetic means. Details of the data collection and calculation procedures are provided in the Nationwide Aquatic Ecological Monitoring Program Report (Ministry of Environment, 2013).

\subsection{Hydrology and water-quality simulations using the SWAT model}

Watershed-health assessment requires the indicator data for the hydrology and water quality to be simulated by the SWAT model. The detailed component selection is presented in Sect. 2.6.3 and 2.6.4. This section briefly summarizes the model data and implementation and the statistical results of the calibration and validation.

\subsubsection{Measured data for the SWAT model evaluation}

The Han River basin was divided into 237 sub-watersheds and 1987 HRUs for SWAT modeling. The sub-watershed delineation was defined by using the $90 \mathrm{~m}$ SRTM DEM from the CIAT. A 2008 land-cover map for nine classes (coniferous forest, deciduous forest, mixed forest, paddy rice, upland crop, urban, grassland, bare field, and water) was obtained from the KME (Fig. 2b). A soil map that contained texture, depth, and drainage attributes was rasterized to a $90 \mathrm{~m}$ grid size from a $1: 25000$ scale vector map that was supplied by the Korea Rural Development Administration (RDA).

The observation data were prepared to evaluate the SWAT model and simulate the hydrological cycle and water quality, including daily meteorological data, dam inflow, dam outflow, dam storage, evapotranspiration, soil moisture, sediments, T-N, and T-P. Thirty-one years (1984-2014) of daily meteorological data (precipitation, maximum and minimum temperature, relative humidity, wind speed, and solar radiation) were collected from 19 weather stations of the KMA. In this study, three multipurpose dams (Hoengseong, Soyang, and Chungju), one hydroelectric dam (Paldang), and three multifunction weirs (Kangcheon, Yeoju, and Ipo) were selected as SWAT-model calibration points (Fig. 2a). For the calibration and validation of the watershed hydrology with dam operations, 10 years (2005-2014) of daily dam inflow, outflow, and storage-volume data for the multipurpose dams were obtained from three water-level stations (Hoengseong Dam, HSD; Soyang Dam, SYD; and Chungju Dam, CJD) that are monitored by the Korea Water Resources Corpora- 
tion and one water-level station (PDD) that is monitored by the Korea Hydro \& Nuclear Power Co., Ltd. In addition, 2 years (2013-2014) of daily measured dam inflow, outflow, and storage volume data for the three multifunction weirs (Kangcheon Weir, KCW; Yeoju Weir, YJW; and Ipo Weir, IPW) that are monitored by the Korea Water Resources Corporation were used. The flow and water quality of the Han River are affected by the discharge operations of these large dams and weirs; therefore, dam and weir operations must be incorporated into the modeling framework to enable successful modeling. In the SWAT model, dam operations are modeled based on measured daily discharges, measured monthly discharges, average annual discharges, or target storage volumes. In this study, the measured daily discharges from the four dams and three weirs were directly imported into the SWAT model.

For the calibration and validation of the stream-water quality, 10 years (2005-2014) of 8-day intervals for sediment, T$\mathrm{N}$, and T-P data were obtained from seven hydrology stations (SG, CSG, JW, KCW, YJW, IPW, and PDD) that are monitored by the KME. Figure 2a shows the gauging stations for the SWAT modeling.

\subsubsection{Calibration and validation of the model}

The SWAT model was calibrated at seven locations in the main river reaches by using 5 years (2005-2009) of daily inflow, storage volume data for the dams and weirs, sediment, T-N, and T-P data and was subsequently validated by using another 5 years (2010-2014) of data with the average calibrated parameters. In addition, the model was spatially calibrated and validated by using evapotranspiration and soil moisture data that were measured at two locations (SM and $\mathrm{CM}$ ) and groundwater level data that were measured at five locations (GPGP, YPGG, YPYD, YIMP, and HCGD) over 5 years (2009-2013).

In this study, uncertainty analysis was performed for the hydrology by using the daily dam inflow using the SUFI-2 method. This method was chosen because of its applicability to both simple and complex hydrological models. SUFI2 is convenient and easy to implement and widely used in hydrology (e.g., Freer et al., 1996; Cameron et al., 2000; Blazkova et al., 2002). In SUFI-2, parameter uncertainty considers all sources of uncertainty, e.g., input uncertainty, conceptual model uncertainty, and parameter uncertainty (Gupta et al., 2005). The degree to which uncertainties are considered is quantified by a measure called the $P$ factor, which is the percentage of the measured data that are bracketed by the $95 \%$ prediction uncertainty (95PPU). Another measure that quantifies the strength of a calibration or uncertainty analysis is the $R$ factor, which is the average thickness of the 95PPU band divided by the standard deviation of the measured data. The excellence of calibration and prediction uncertainty is judged based on the closeness of the $P$ factor to 1 and the closeness of the $R$ factor to 0 . Twenty parame- ters were selected by sensitivity analysis for the uncertainty analysis. In this study, three iterations were performed with $1300(100+200+1000)$ model runs in each iteration. The coverages of the measurements $(P$ factor) and the average thickness ( $R$ factor) of the 95PPUs for the model predictions were 0.79 and 0.32 , respectively, for the dam inflow during the calibration and validation periods.

In this study, both calibration and validation were manually performed by using a trial-and-error approach within recommended ranges to maximize the expert knowledge of watershed characteristics and modeling experience. The final values were selected based on a statistical evaluation of the performance measures. Twenty of the most influential parameters were selected for calibration. These parameters are related to surface-runoff $(\mathrm{CN} 2$, CNCOEF, SURLAG, OV_N, and CH_N), evapotranspiration (ESCO), soil-water (SOL_AWC and SOL_K), groundwater (GW_DELAY, GWQMN, ALPHA_BF, REVAPMN, and GW_REVAP), and reservoir-operation (RES_ESA, RES_EVOL, RES_PSA, RES_PVOL, RES_VOL, RES_K, and EVRSV) processes. The calibrated parameters and hydrograph of the calibration results in the Han River basin were described by Chung et al. (2017).

The statistical results for the hydrology and water quality for the model calibration and validation are summarized in Table 2. The coefficient of determination $\left(R^{2}\right)$, the Nash and Sutcliffe model efficiency (NSE), the root-mean-square error (RMSE), and the percent bias (PBIAS) were used to evaluate the ability of the SWAT model to replicate temporal trends in the observed hydrological and water-quality data. The $R^{2}$ value for the dam inflow was greater than 0.59 . The average NSE was 0.59 at HSD, 0.78 at SYD, 0.61 at CJD, 0.79 at KCW, 0.77 at YJW, 0.88 at IPW, and 0.87 at PDD. The PBIAS values of HSD, CJD, SYD, KCW, YJW, IPW, and PDD were $13.5,12.2,9.4,11.5,19.8,21.4$, and $4.5 \%$, respectively. The average $R^{2}$ for the dam-storage volume was between 0.40 and 0.96 and the PBIAS was between 0.9 and $18.9 \%$ for each calibration point. The average $R^{2}$ for evapotranspiration was between 0.70 and 0.81 , that for the soil moisture was between 0.75 and 0.85 , and that for the groundwater level was between 0.40 and 0.70 for each calibration point. The average $R^{2}$ for the sediment was between 0.54 and 0.90 , that for the T-N was between 0.46 and 0.82 , and that for the T-P was between 0.47 and 0.80 for each calibration point. The calibration results were consistent with the SWAT calibration guidelines (NSE $\geq 0.5$, PBIAS $\leq 28 \%$, and $R^{2} \geq 0.6$; Moriasi et al., 2007; Santhi et al., 2001) and were found to be satisfactory. Additionally, the model calibration and validation included the NSE with inverse discharge $(1 / Q)$ for low flow. The average NSE with inverse discharge $(1 / Q)$ during the calibration (2005-2009) and validation (2010-2014) periods was 0.35 at $\mathrm{HSD}, 0.53$ at $\mathrm{SYD}, 0.30$ at CJD, 0.54 at $\mathrm{KCW}, 0.47$ at YJW, 0.69 at IPW, and 0.58 at PDD. 
Table 2. Calibration and validation results for the dam inflow, dam-storage volume, evapotranspiration and soil moisture, groundwater-level fluctuation, sediments, T-N, and T-P at each calibration point.

\begin{tabular}{|c|c|c|c|c|c|c|c|c|c|c|c|c|c|c|c|}
\hline Model output & Evaluation criteria & Cal. & Val. & Cal. & Val. & Cal. & Val. & Cal. & Val. & Cal. & Val. & Cal. & Val. & Cal. & Val. \\
\hline \multirow{6}{*}{$\begin{array}{l}\text { Dam inflow } \\
(\mathrm{mm})\end{array}$} & Locations & \multicolumn{2}{|c|}{ HSD } & \multicolumn{2}{|c|}{ SYD } & \multicolumn{2}{|c|}{ CJD } & \multicolumn{2}{|c|}{$\mathrm{KCW}$} & \multicolumn{2}{|c|}{ YJW } & \multicolumn{2}{|c|}{ IPW } & \multicolumn{2}{|c|}{ PDD } \\
\hline & $R^{2}$ & 0.82 & 0.84 & 0.90 & 0.89 & 0.81 & 0.74 & 0.90 & 0.63 & 0.91 & 0.62 & 0.93 & 0.59 & 0.92 & 0.88 \\
\hline & NSE & 0.61 & 0.57 & 0.78 & 0.78 & 0.63 & 0.58 & 0.78 & 0.79 & 0.77 & 0.76 & 0.81 & 0.95 & 0.83 & 0.76 \\
\hline & $\operatorname{NSE}(1 / Q)$ & 0.44 & 0.26 & 0.49 & 0.56 & 0.34 & 0.25 & 0.47 & 0.60 & 0.46 & 0.47 & 0.62 & 0.75 & 0.65 & 0.51 \\
\hline & $\operatorname{RMSE}\left(\mathrm{mm} \mathrm{day}^{-1}\right)$ & 7.9 & 9.3 & 3.8 & 3.9 & 3.5 & 3.1 & 6.5 & 0.7 & 9.1 & 2.4 & 9.2 & 2.9 & 0.8 & 2.3 \\
\hline & PBIAS (\%) & 14.5 & 12.5 & 10.3 & 14.0 & 8.9 & 9.9 & 18.0 & 4.9 & 25.5 & 14.1 & 25.6 & 17.2 & 2.2 & 6.8 \\
\hline \multirow{3}{*}{$\begin{array}{l}\text { Dam storage } \\
\left(10^{6} \mathrm{~m}^{3}\right)\end{array}$} & & \multicolumn{2}{|c|}{ HSD } & \multicolumn{2}{|c|}{ SYD } & \multicolumn{2}{|c|}{ CJD } & \multicolumn{2}{|c|}{$\mathrm{KCW}$} & \multicolumn{2}{|c|}{ YJW } & \multicolumn{2}{|c|}{ IPW } & \multicolumn{2}{|c|}{ PDD } \\
\hline & $R^{2}$ & 0.73 & 0.77 & 0.94 & 0.96 & 0.87 & 0.84 & 0.57 & 0.85 & 0.47 & 0.83 & 0.47 & 0.79 & 0.40 & 0.44 \\
\hline & PBIAS (\%) & 18.9 & 9.9 & 16.3 & 9.3 & 18.2 & 15.2 & 5.1 & 7.4 & 3.7 & 11.1 & 9.1 & 7.2 & 0.9 & 1.4 \\
\hline \multirow{5}{*}{$\begin{array}{l}\text { Evapotrans- } \\
\text { piration (mm) }\end{array}$} & Locations & \multicolumn{2}{|c|}{ SM } & \multicolumn{2}{|c|}{$\mathrm{CM}$} & \multicolumn{2}{|c|}{-} & \multicolumn{2}{|c|}{-} & \multicolumn{2}{|c|}{-} & \multicolumn{2}{|c|}{ - } & \multicolumn{2}{|c|}{-} \\
\hline & $R^{2}$ & 0.81 & 0.73 & 0.70 & 0.74 & - & - & - & - & - & - & - & - & - & - \\
\hline & NSE & 0.64 & 0.45 & 0.50 & 0.55 & - & - & - & - & - & - & - & - & - & - \\
\hline & $\operatorname{RMSE}\left(\mathrm{mm} \mathrm{day}^{-1}\right)$ & 2.3 & 9.1 & 4.0 & 3.0 & - & - & - & - & - & - & - & - & - & - \\
\hline & PBIAS (\%) & 9.6 & 30.2 & 11.6 & 23.7 & - & - & - & - & - & - & - & - & - & - \\
\hline Soil moisture & Locations & \multicolumn{2}{|c|}{ SM } & \multicolumn{2}{|c|}{$\mathrm{CM}$} & \multicolumn{2}{|c|}{-} & \multicolumn{2}{|c|}{-} & \multicolumn{2}{|c|}{-} & \multicolumn{2}{|c|}{ - } & & \\
\hline$(\%)$ & $R^{2}$ & 0.85 & 0.75 & 0.78 & 0.78 & - & - & - & - & - & - & - & - & - & - \\
\hline Groundwater & Locations & & & & & & & & & & & & & & \\
\hline level (EL.m) & $R^{2}$ & - & - & - & - & 0.70 & 0.63 & 0.64 & 0.45 & 0.70 & 0.41 & 0.53 & 0.40 & 0.69 & 0.67 \\
\hline & Locations & & & & & & & & & & & & & & \\
\hline Sediment (tons) & $R^{2}$ & 0.78 & 0.70 & 0.78 & 0.76 & 0.90 & 0.71 & 0.54 & 0.64 & 0.84 & 0.54 & 0.69 & 0.66 & 0.72 & 0.80 \\
\hline $\mathrm{T}-\mathrm{N}(\mathrm{kg})$ & $R^{2}$ & 0.58 & 0.71 & 0.64 & 0.71 & 0.82 & 0.68 & 0.50 & 0.61 & 0.52 & 0.49 & 0.46 & 0.62 & 0.66 & 0.62 \\
\hline $\mathrm{T}-\mathrm{P}(\mathrm{kg})$ & $R^{2}$ & 0.77 & 0.77 & 0.88 & 0.88 & 0.80 & 0.56 & 0.56 & 0.58 & 0.50 & 0.47 & 0.66 & 0.70 & 0.74 & 0.69 \\
\hline
\end{tabular}

${ }^{a}$ Cal.: calibration period (HSD, SYD, CJD, and PDD: 2005-2009; KCW, YJW, and IPW: 2013); Val.: validation period (HSD, SYD, CJD, and PDD: 2010-2014; KCW, YJW, and IPW: 2014).

\subsection{Data reconstruction for the watershed-health assessment}

\subsubsection{Landscape condition}

The area of natural land cover (forest, wetland, river, and natural grassland) within a watershed can be an important indicator of watershed health. Impervious land cover that is associated with roads and residential and urban areas can increase watershed runoff, leading to instream flow alteration, geomorphic instability, and increased pollutant loading. According to previous studies, a smaller area of impervious land cover may significantly affect aquatic ecosystem health (e.g., King et al., 2011; Wang and Yin, 1997).

The extent and connectivity of the natural land cover within a watershed are very important for ecological integrity. Natural land cover within the watershed, and especially within headwater areas and riparian corridors, maintains the hydrologic regime, regulates the inputs of nutrients and organic matter, and provides habitats for fish and wildlife (U.S. EPA, 2012). In this study, assessing the connectivity of the natural land cover (forest, wetland, river, and natural grassland) of watersheds involved a green-area assessment; green areas comprise areas of unfragmented natural land cover and corridors of sufficient width to allow the migration of wildlife between the watersheds (Fig. 3a). For the
237 sub-watersheds of the Han River basin, the percentage of each watershed area that was occupied by natural land cover (habitat blocks) was calculated by using GIS techniques. The green area metric was calculated as follows:

Green area metric $=$

$$
\frac{\operatorname{Area}\left(\mathrm{km}^{2}\right) \text { of natural land cover in watershed }}{\text { Total area }\left(\mathrm{km}^{2}\right) \text { in watershed }} \text {. }
$$

The amount of natural land cover within the active river area is another important indicator of the landscape condition. The natural land cover within the active river area, including the river channel, lakes and ponds, and the riparian lands, is necessary for the physical and ecological functioning of the aquatic ecosystem (U.S. EPA, 2012). Active river areas, in their natural state, maintain the ecological integrity of rivers, streams, and riparian areas and the connection of these areas to the local groundwater system (IPCC, 2007). The methods that are used to delineate the active river area involve GIS techniques and analyses of elevation, land-cover, and wetland data. For streamside areas for which criteria have not yet been decided, an area with a width of $30-50 \mathrm{~m}$ can be used as a cutoff to identify streamside material contribution areas (U.S. EPA, 2012). In this study, the percentage of natural land cover within the riparian area within $50 \mathrm{~m}$ of the stream was calculated for the 237 sub-watersheds in the Han 

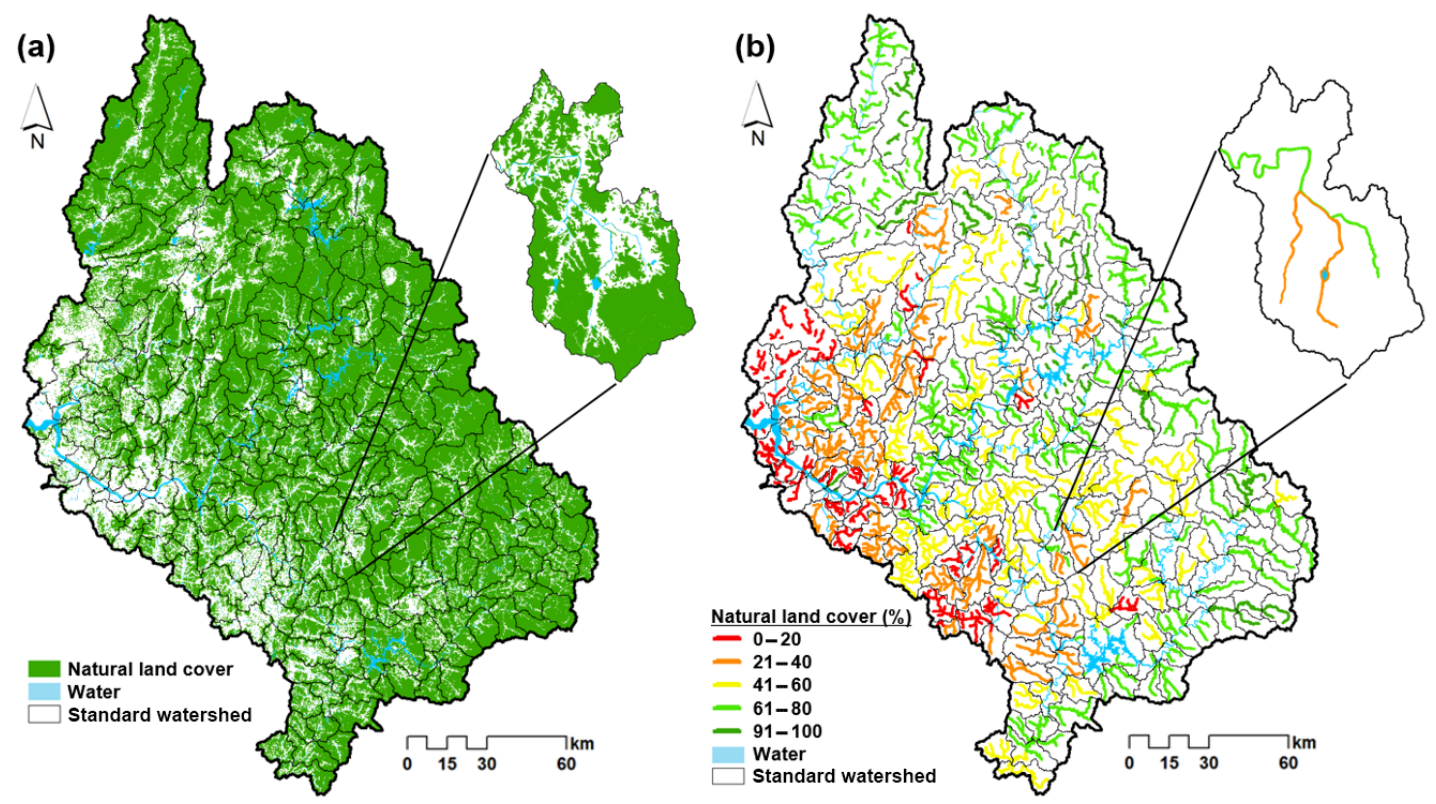

Figure 3. Landscape condition for the (a) green area and (b) riparian area.

River basin by using GIS techniques (Fig. 3b). The active river area metric was calculated as follows:

Active river area metric $=$

Area $\left(\mathrm{km}^{2}\right)$ of natural land cover in active river area

Total area $\left(\mathrm{km}^{2}\right)$ in active river area

\subsubsection{Stream geomorphic condition}

The natural stream geomorphology can be an important indicator of watershed health because it can fragment both the terrestrial and aquatic habitats throughout a watershed. Kline et al. (2009) performed detailed assessments of stream geomorphic conditions by using the Vermont Stream Geomorphic Assessment Protocols for streams in Vermont, USA. These assessment protocols are GIS-based analyses that use elevation, land cover, and stream network data layers to classify stream types and evaluate the conditions of individual reaches based on a comparison to reference conditions for that stream type.

Table 3 provides descriptions of the stream geomorphic conditions that are determined through the stream-impact rating and the stream order for the watershed-health assessment of the geomorphic condition in the Han River basin. In this study, the geomorphic condition was assessed in a similar manner to what was used for the stream-condition categories of the Vermont Stream Geomorphic Assessment Protocols. The stream order was calculated for nine levels (Fig. 4a) by using a DEM and stream map, and four river classifications were created through follow-up analyses with detailed landcover assessments (Fig. 4b). Four river classifications were used: reference (mountainous river, stream order 1), good (small river, stream orders 2-3), fair (local river, stream orders 4-5), and poor (urban and national river, stream orders 6-9). The percentage of the assessed stream length in the reference condition was calculated for each watershed. The stream geomorphology metric was calculated as follows:

Stream geomorphology metric $=$

Stream length $(\mathrm{km})$ of reference condition in watershed

Total stream length $(\mathrm{km})$ in watershed

\subsubsection{Hydrologic condition}

The assessment of the hydrologic condition of a watershed requires long-term streamflow observation data for the 237 sub-watersheds of the Han River basin. However, insufficient gauging stations were available to fully assess the entire watershed over the entire 30-year period. No data were available for the water-balance components that were associated with surface-groundwater interactions, except for the streamflow. Where unavailable, these long-term flow data could be estimated by using hydrologic modeling techniques. Thus, the SWAT hydrologic model was used to simulate the waterbalance components within the Han River basin.

To simulate the potentially available water quantity of the basin, the model was applied by dividing the basin into 237 sub-watersheds according to the operation of water-resource facilities (inflow and storage volume) in three multipurpose dams, one hydroelectric dam, and three multifunction weirs. The SWAT simulation outputs - including PREC and TQ for the total processes; SQ for the surface processes; INFILT, SW, and LQ for the soil water dynamics; and PERCOL, RECHARGE, and GWQ for the groundwater dynamics - of 

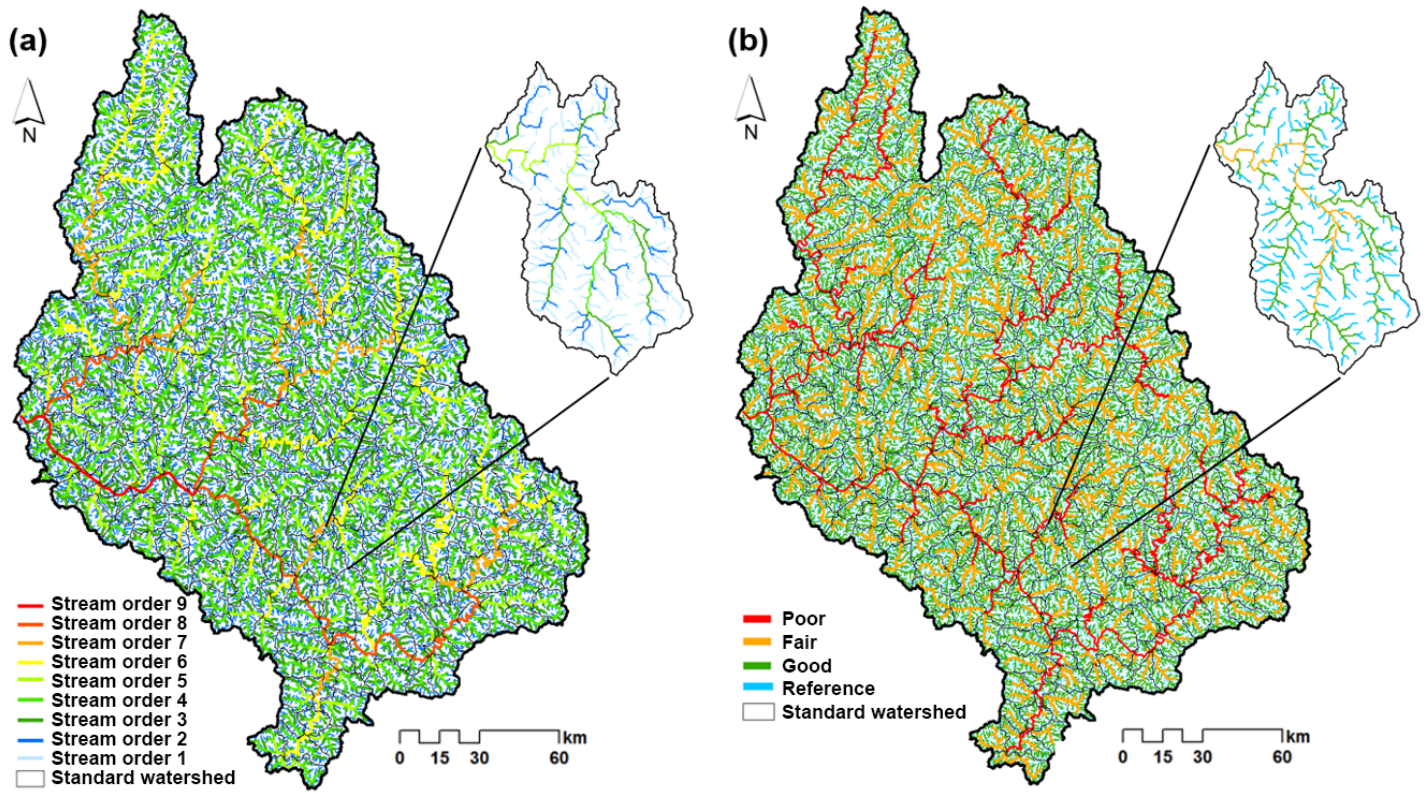

Figure 4. Stream geomorphic conditions: (a) stream order and (b) stream geomorphic conditions.

Table 3. Description of the stream geomorphic conditions (Kline et al., 2009) and stream order for the watershed-health assessment of the geomorphic condition in the Han River basin.

\begin{tabular}{llll}
\hline Condition & Description & $\begin{array}{l}\text { River } \\
\text { classification }\end{array}$ & $\begin{array}{l}\text { Stream order } \\
(1-9)\end{array}$ \\
\hline Reference & $\begin{array}{l}\text { In equilibrium - no apparent or significant channel, floodplain, or land- } \\
\text { cover modifications; the channel geometry is likely to be in balance with } \\
\text { the flow and sediment that are produced in its watershed. }\end{array}$ & $\begin{array}{l}\text { Mountainous } \\
\text { river }\end{array}$ & 1 \\
\hline Good & $\begin{array}{l}\text { In equilibrium but may be in transition into or out of the range of natural } \\
\text { variability - minor erosion or lateral adjustment but adequate floodplain } \\
\text { function; any adjustments from historical modifications nearly complete. }\end{array}$ & & Small river \\
& $\begin{array}{l}\text { In adjustment - moderate loss of floodplain function or moderate to major } \\
\text { plan-form adjustments that could lead to channel avulsions. }\end{array}$ & Local river & $4-5$ \\
\hline Fair & $\begin{array}{l}\text { In adjustment and stream type departure - may have changed to a new } \\
\text { stream type, or central tendency of fluvial processes or significant chan- } \\
\text { nel and floodplain modifications may have altered the channel geometry } \\
\text { such that the stream is not in balance with the flow and sediment that are } \\
\text { produced in its watershed. }\end{array}$ & National river & $6-9$ \\
\hline Poor & & & \\
& & & \\
\hline
\end{tabular}

each of the 237 sub-watersheds were reported. All the results of the SWAT model were output in millimeters.

The annual average water-balance components at the surface, in the unsaturated zone, and in a shallow aquifer can serve as indicators of potential hydrologic alteration. Surface-water and lateral groundwater flow interactions are very important for the water balance in the Han River basin. In particular, the infiltration, return flow, and groundwater recharge are important factors for the entire hydrological cycle. In this study, the SWAT model results were used to reconstruct daily time series for the PREC, TQ, SQ, INFILT, SW,
LQ, PERCOL, RECHARGE, and GWQ hydrologic components over a 30-year period (1985-2014) (Fig. 5). The annual average value for the 237 sub-watersheds during this period was used as the reference condition (Table 4). Dividing the simulated value of the watershed by the reference condition yielded the storage ratio of the nine components. The storage ratios of the nine components were divided into four hydrologic classifications - the total metric (PREC and TQ), surface process metric (SQ), soil water dynamics metric (INFILT, SW, and LQ), and groundwater dynamics metric (PERCOL, RECHARGE, and GWQ) - to establish specific man- 


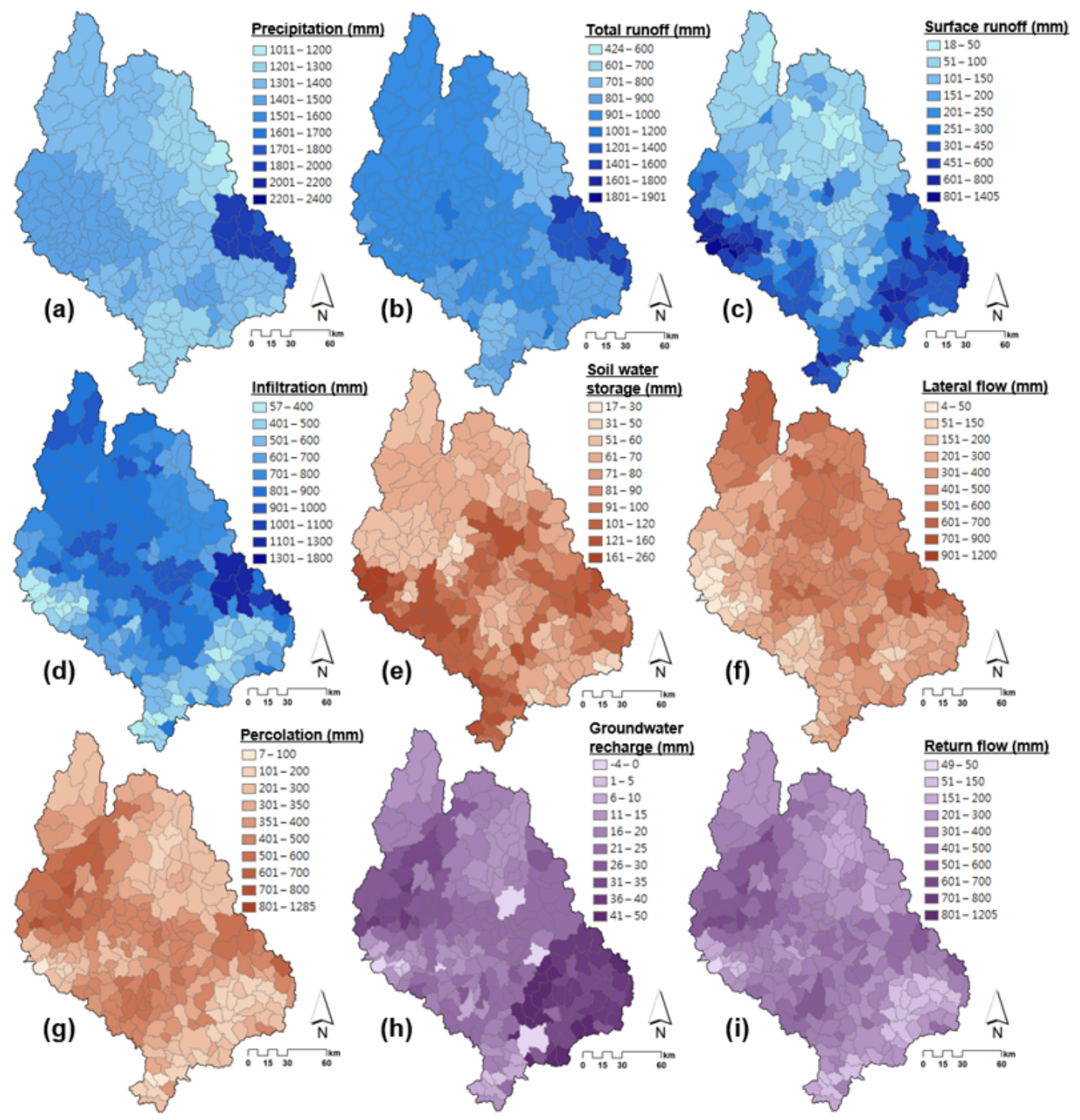

Figure 5. Hydrologic condition for the (a) precipitation, (b) total runoff, (c) surface runoff, (d) infiltration, (e) soil water storage, (f) lateral flow, (g) percolation, (h) groundwater recharge, and (i) return flow according to the hydrological (SWAT) modeling for the period from 1985 to 2014 in the Han River basin.

agement objectives. The storage ratio of each component for the four hydrology metrics was calculated for each watershed and used as a metric of the hydrologic condition. The hydrology metric was calculated as follows:

Hydrology metric $=$

Simulated value $(\mathrm{mm})\left(^{*}\right)$ of watershed

Average value (mm) for all watersheds in basin

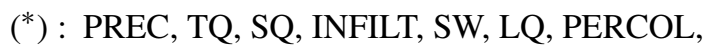

RECHARGE, and GWQ

\subsubsection{Water-quality condition}

Assessing the water quality of a watershed also requires longterm observational data from the 237 sub-watersheds of the Han River basin. However, the monitoring data for water quality are not exhaustive and not sufficient to analyze longterm changes. In this study, the SWAT model was used to simulate the water-quality sediment loads (tons), T-N (kg), and the T-P $(\mathrm{kg})$ within the Han River basin.

The SWAT-model results were used to reconstruct loadbased daily time series for the water-quality constituent sediments $\left(\mathrm{mg} \mathrm{L}^{-1}\right)$, T-N $\left(\mathrm{mg} \mathrm{L}^{-1}\right)$, and T-P $\left(\mathrm{mg} \mathrm{L}^{-1}\right)$ over a 


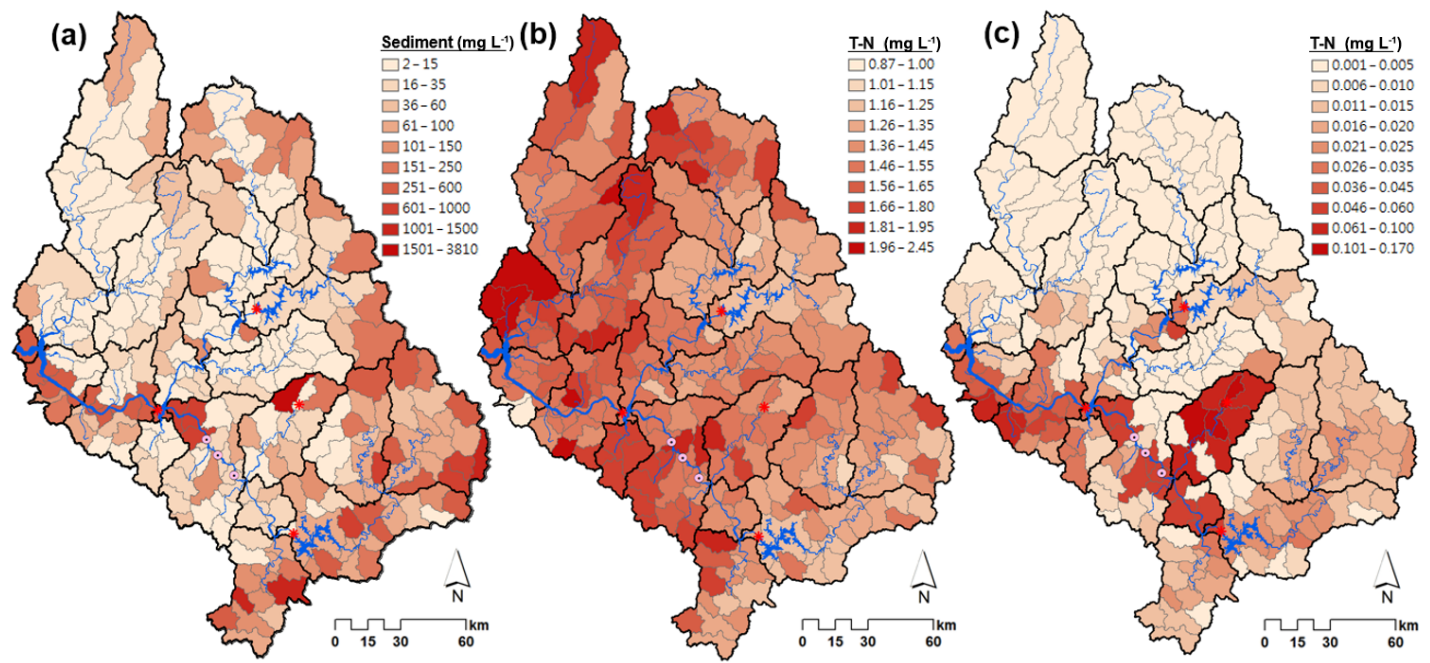

Figure 6. Water-quality condition for the (a) sediment, (b) T-N, and (c) T-P according to the hydrological (SWAT) modeling for the period from 1985 to 2014 in the Han River basin.

Table 4. Summary of the hydrology, water-quality, and biological criteria that were used to screen for the reference condition in the Han River basin.

\begin{tabular}{|c|c|c|}
\hline Component & Source & Reference condition \\
\hline \multicolumn{3}{|l|}{ Hydrology } \\
\hline Precipitation & River-basin average of 30 years (1985-2014) as simulated by SWAT & $1395.1(\mathrm{~mm})$ \\
\hline Total runoff & & $919.5(\mathrm{~mm})$ \\
\hline Surface runoff & & $249.4(\mathrm{~mm})$ \\
\hline Infiltration & & $726.4(\mathrm{~mm})$ \\
\hline Soil water storage & & $85.3(\mathrm{~mm})$ \\
\hline Lateral flow & & $345.9(\mathrm{~mm})$ \\
\hline Percolation & & $363.8(\mathrm{~mm})$ \\
\hline Groundwater recharge & & $22.9(\mathrm{~mm})$ \\
\hline Return flow & & $324.2(\mathrm{~mm})$ \\
\hline \multicolumn{3}{|l|}{ Water quality } \\
\hline Sediment & Levels greater than the "marginally good" level on a seven-point scale (ex- & $15\left(\mathrm{mg} \mathrm{L}^{-1}\right)$ \\
\hline $\mathrm{T}-\mathrm{N}$ & cellent, very good, good, marginally good, fair, poor, very poor) of water- & $0.6\left(\mathrm{mg} \mathrm{L}^{-1}\right)$ \\
\hline $\mathrm{T}-\mathrm{P}$ & $\begin{array}{l}\text { quality criteria for streams and lakes as devised by the Basic Environmental } \\
\text { Policy Act (BEPA) in South Korea. }\end{array}$ & $0.05\left(\mathrm{mg} \mathrm{L}^{-1}\right)$ \\
\hline \multicolumn{3}{|l|}{ Biological condition } \\
\hline TDI & "Best" and "good" levels on a four-point scale (best, good, fair, and poor) & 72.5 \\
\hline BMI & of biological condition criteria devised by the Korea Ministry of Environ- & 80.0 \\
\hline FAI & ment (KME) (Ministry of Environment, 2013). & 78.1 \\
\hline
\end{tabular}

30-year period (1985-2014) (Fig. 6). As part of the Basic Environmental Policy Act (BEPA), South Korea has specified eco-regional water-quality criteria to identify the leastdisturbed sites throughout South Korea. These criteria were used to identify the streams and lakes that are likely to be in the reference condition based on their sediment, T-N, and T-P concentrations. The "marginally good" level of a seven-point scale (excellent, very good, good, marginally good, fair, poor, very poor) of water-quality criteria for streams and lakes was used for the reference condition (Table 4). The percentage of the assessed values in the reference condition was calculated for each watershed. The water-quality metric was calculated as follows:

Water quality metric $=$

Simulated value $\left(\mathrm{mg} \mathrm{L}^{-1}\right)$ (sediment, T-N, and T-P) of watershed Reference value $\left(\mathrm{mgL}^{-1}\right)$ in watershed 

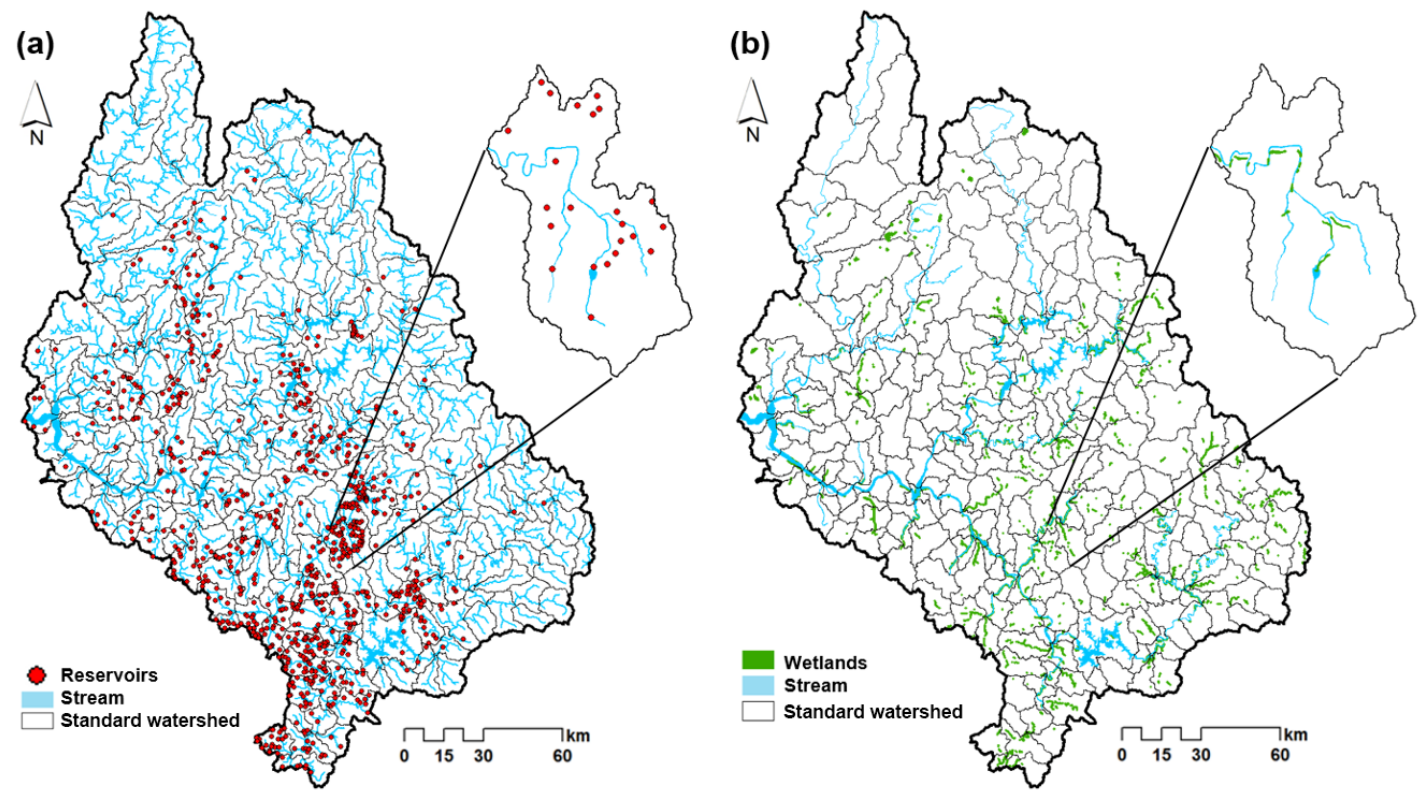

Figure 7. Aquatic habitat conditions for the (a) aquatic habitat connectivity and (b) wetlands.

\subsubsection{Aquatic habitat condition}

The quality of aquatic habitats depends on the surrounding landscape and hydrologic and geomorphic processes. Therefore, the habitat condition is affected by indicators that represent these assessment components. The potential for organisms to migrate upstream and downstream within a riverine system can also serve as an indicator of the aquatic habitat condition. Lakeshores also have riparian zones that serve as a source of organic material to the lake aquatic habitat and help stabilize the lake perimeter (U.S. EPA, 2012). The EPA's National Lakes Assessment (NLA) identified poor lakeshore habitats as the most prominent stressor to the biological health of lakes (U.S. EPA, 2009). The density of reservoirs per stream length was calculated and used as an indicator of aquatic-habitat connectivity (Fig. 7a). The aquatic habitat connectivity metric was calculated as follows:

Aquatic habitat connectivity metric $=$

Number of reservoirs in watershed

Total stream length $(\mathrm{km})$ in watershed

Intact wetlands maintain natural hydrologic regimes, provide important habitats for fish and wildlife, and regulate water quality. The percentage of the watershed that was occupied by wetlands was calculated and used as an additional indicator of the habitat condition for each watershed (Fig. 7b). The wetland metric was calculated as follows:

Wetland metric $=$

Area $\left(\mathrm{km}^{2}\right)$ of wetlands in watershed

Total area $\left(\mathrm{km}^{2}\right)$ in watershed

\subsubsection{Biological condition}

Based on the understanding that aquatic ecological environmental degradation is one of the leading causes of stream impairment, the Ministry of Environment of South Korea began collecting variables of biological community diversity as a component of its Nationwide Aquatic Ecological Monitoring Program for a 6-year period (2008-2013). Three biological indicators (TDI, BMI, and FAI) were chosen based on a statistical evaluation of these data to identify healthy instream conditions for the Han River basin. In the Han River basin, the TDI, BMI, and FAI were developed from epilithic diatoms, benthic macro-invertebrates, and fish assessments to estimate the overall biological condition during the 6year period (2008-2013); these data can be used to identify healthy instream conditions in the context of aquatic ecosystem health. Healthy watersheds should have TDI, BMI, and FAI scores that are close to the reference conditions. Indices with a range from 0 to 100 were classified on a four-point scale of best, good, fair, and poor for the biological condition criteria according to the Nationwide Aquatic Ecological Monitoring Program Report (Ministry of Environment, 2013), and the best and good levels were used as the reference condition (Table 3). The percentage of the assessed scores on the TDI, BMI, and FAI in the reference condition was calculated for each watershed (Fig. 8). The biological condition metric was calculated as follows:

Biological condition metric $=$

Observed value (TDI, BMI, and FAI) of watershed

Reference value for watershed 


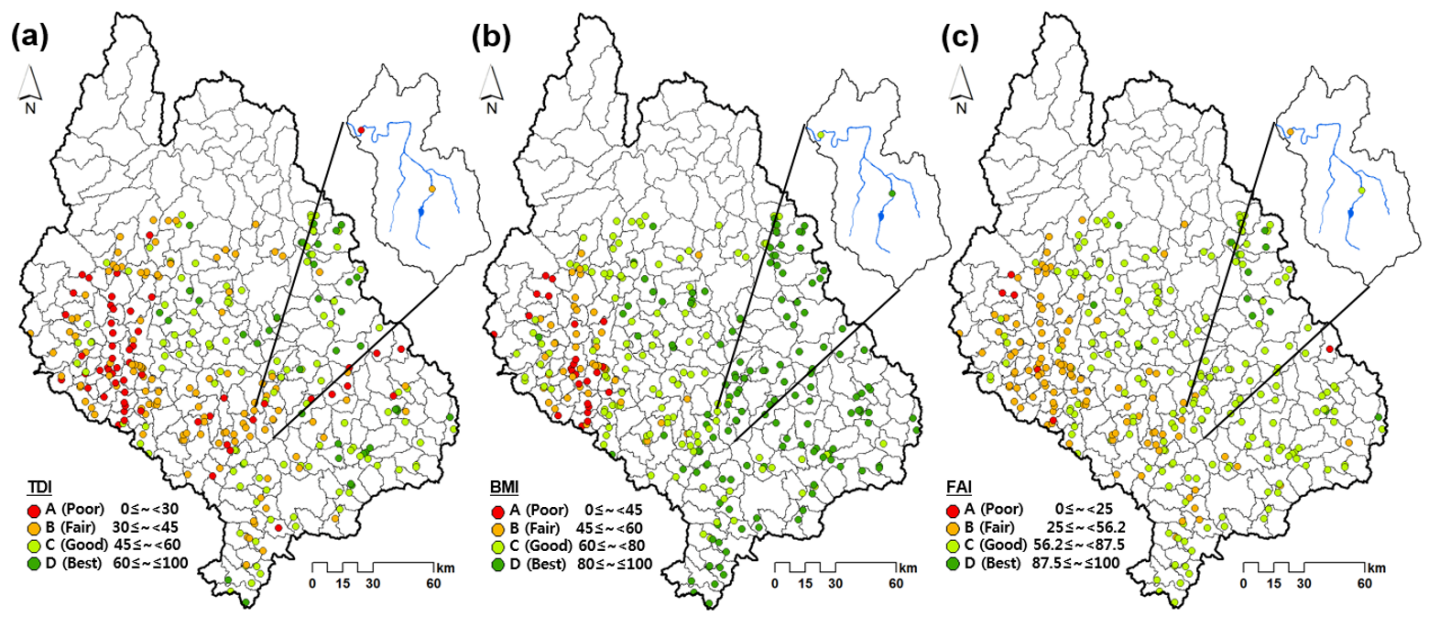

Figure 8. Biological conditions of the (a) FAI, (b) BMI, and (c) FAI according to the observed monitoring data for the period from 2008 to 2013 in the Han River basin.

\subsection{Watershed-health index formulation}

The definition of the watershed-health index was created by the U.S. EPA for integrated watershed-health evaluations. The watershed health was evaluated by normalizing the metric scores to integrate the data on multiple healthy watershed attributes into a composite score. Normalization was conducted by simply defining a reference value for the indicator score that was considered healthy based on the percentile rank. For communication purposes, the indicator score was scaled to normalize the final sub-index and Watershed Health Index scores to range from 0 to 1 . Table 4 shows the definition of the "healthy" reference value for the hydrology, water-quality, and biological indicators. The indicator scores must also be directionally aligned, meaning that higher scores should equate to "better" conditions for each metric. The inverse $(1 / X)$ of each value can be taken for metrics that are not directionally aligned in their original units (e.g., water-quality components).

A composite index of the watershed health was constructed by averaging the normalized indicator scores for each attribute. A sub-index was calculated first for attributes with more than one indicator. The sub-indices were then averaged to obtain the integrated watershed-health index score (U.S. EPA, 2012). Depending on the specific management objectives, placing more weight on some ecological attributes than on others and using optional sub-indices may be appropriate. At this point, the process becomes subjective and a logical decision framework can be used to solicit and document expert opinions (Smith et al., 2003). Weighting was not used in this study for integrated assessment. The normalized metrics, sub-index, and integrated watershed-health index were calculated as follows:
Normalized metric value $=$

Observed or simulated metric for watershed $x$

Reference metric value for all watersheds in basin

Sub-index $=$

(Normailzed metric1 + Normalized metric $2+\ldots+$ Normalized metric $x$ ) Total number of metrics

Watershed health index $=$

(sub-index $1+\operatorname{sub}-$ index $2+\ldots+\operatorname{sub}-$ index $x$ )

Total number of sub-indices

\section{Results and discussion}

\subsection{Watershed health by each component in the Han River basin}

Watershed-health analysis for each component was conducted in the 237 sub-watersheds of the Han River basin by using the data reconstruction results for the six components. The sampling areas that were used to explain the differences in the watershed-health results for each component were the standard watersheds 101206 (urban $1.4 \%$ and forest $88.1 \%$ ), 100201 (urban $0.8 \%$ and forest $88.2 \%$ ), and 101801 (urban $9.8 \%$ and forest 5\%) (Fig. 2a). The 101206 , 100201 , and 101801 standard watersheds are located in the upstream region of the Soyang Dam (SYD), in the upstream region of the Chungju Dam (CJD), and in the downstream region of the Paldang Dam (PDD), respectively.

Figure 12a shows the sub-index scores for the watershedhealth assessment according to two assessment indicators (Fig. 3). The spatial patterns of the watershed health for green areas were healthier in upstream watersheds because the natural land cover was greater the farther the watersheds 

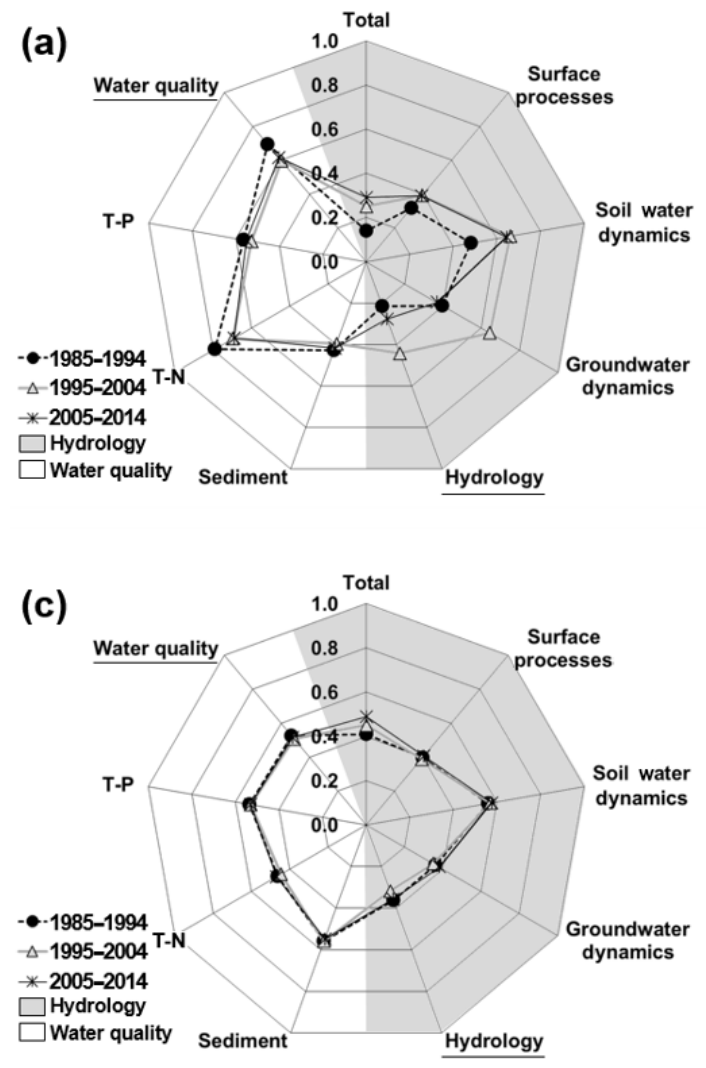
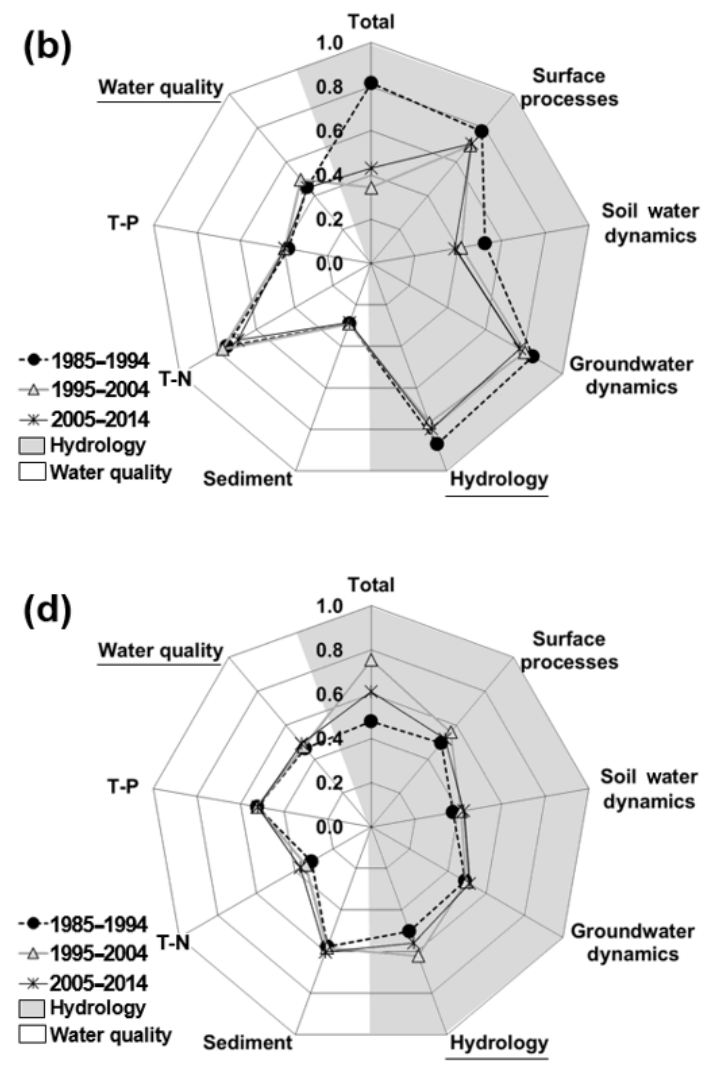

Figure 9. Change in hydrology and water quality for the (a) A (SYD watershed), (b) B (CJD watershed), (c) C (PDD watershed), and (d) D (lower watershed) test areas for three 10-year periods.

were from urban areas. The spatial patterns of the watershed health for the active river area within $50 \mathrm{~m}$ of a stream were healthier for the upstream watersheds for the same reason. For the 101206 standard watershed, the normalized values of the green area and the active river area were 0.93 and 0.82 , respectively, and the sub-index score of 0.89 , which integrated the two normalized values, indicated a very healthy watershed. For the 100201 standard watershed, the normalized values of the green area and the active river area were 0.78 and 0.57 , respectively, and the sub-index score of 0.66 , which integrated the two normalized values, indicates a less healthy watershed. In contrast, the 101801 standard watershed was revealed to be in very poor health, with a score of 0.17 for the sub-index, while the normalized values of the green area and active river area were 0.25 and 0.09 , respectively. Hence, this study found that the downstream reaches of the Han River basin are in greater need of green areas and active river areas compared to the upstream reaches.

Figure $12 \mathrm{~b}$ shows the sub-index scores for the watershedhealth assessment when using stream geomorphology indicators (Fig. 4). The percentage of the length of the assessed stream channel in the reference condition was greater for the upstream watershed than for the downstream watershed. The high-gradient mountainous streams in the upstream wa- tershed are characterized by relatively clean streams that have not been subject to land-cover modifications or riverimprovement work.

The sub-index results of the hydrologic (Fig. 5) and waterquality (Fig. 6) conditions are shown in Fig. 12c and d, respectively. The precipitation in the watershed directly affects the surface runoff and sediment transport and is the most important factor that affects the maintenance of the water quantity, and can thus be used to identify critical areas for maintaining watershed health. Nutrient (T-N and T-P) loads are often correlated with surface runoff and sediment transport rates (USDA-SCS, 1972). The fugitive sediment from the landscape is carried by overland flow (surface runoff), and the dominant pathway for nitrate loss is through leaching into groundwater and then via baseflow (Randall and Mulla, 2001).

The sub-indices of the hydrologic condition that were calculated by the four hydrologic classifications, such as the total metric, surface process metric, soil water dynamics metric, and groundwater dynamics metric, and the water-quality condition that was calculated by the sediment, T-N, and T$\mathrm{P}$ were split into three periods of 10 years - 1985-1994, 1995-2004, and 2005-2014 - to assess changes over time (Fig. 9). The test areas that were used to explain the dif- 


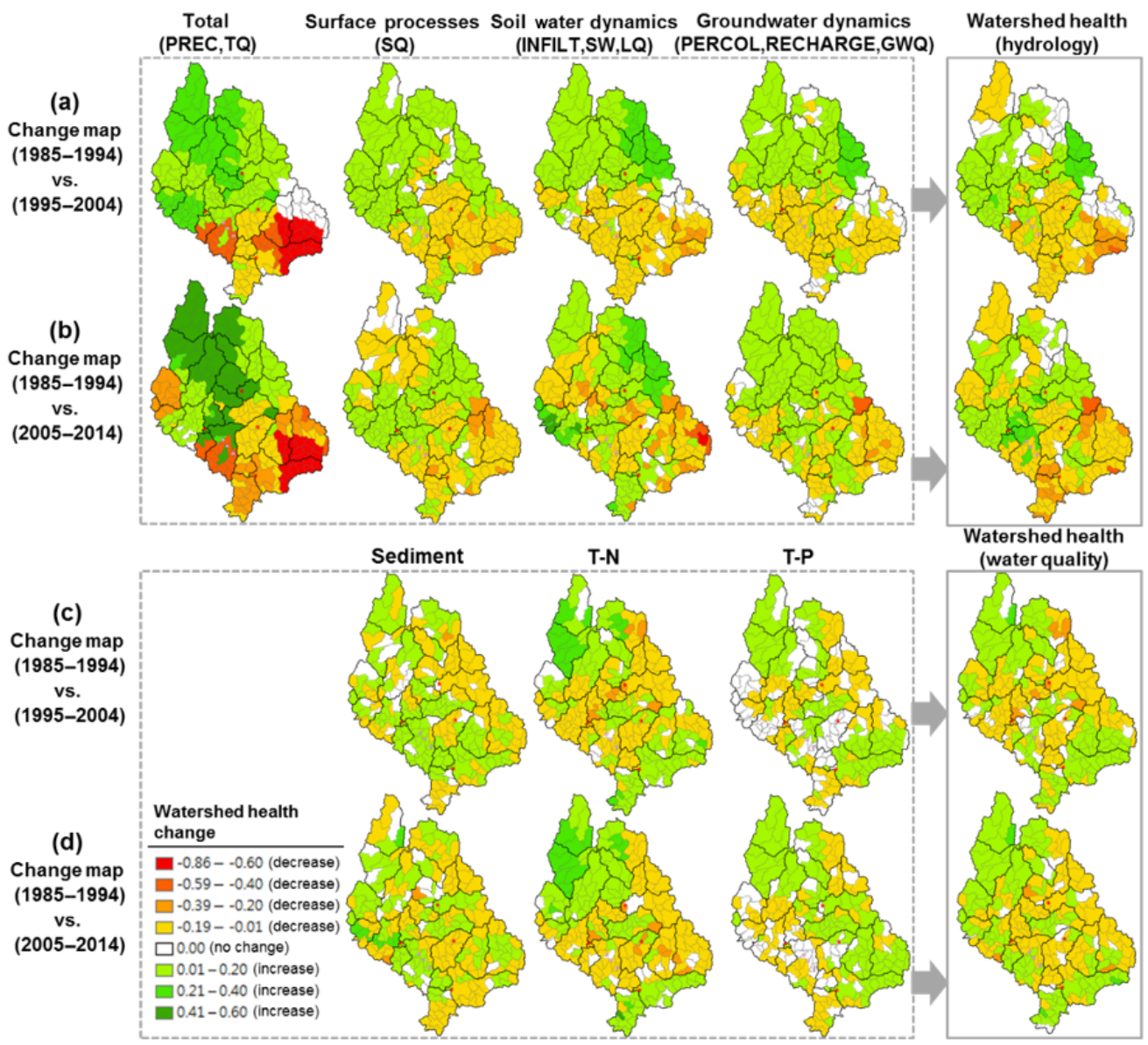

Figure 10. Watershed-health index score changes for the hydrologic (a, b) and water-quality (c, d) conditions during the period 1995-2004 and the most recent 10-year period (2005-2014) based on the reference period (1985-1994).

ferences in the watershed-health results for the hydrologic and water-quality components were the SYD and CJD watersheds in the upstream region and the PDD and lower watersheds in the downstream region (Fig. 2c). For the SYD watershed (Fig. 9a), the watershed-health scores of the surface water, soil water, and groundwater hydrology increased in the recent past compared to the period 1985-1994 because of the slight increases in PREC and TQ; thus, the watershed water quality decreased. The health of the hydrology in the CJD watershed showed a decreasing tendency in contrast to the SYD watershed because of the decrease in PREC and TQ (Fig. 9b). The groundwater of the PDD watershed was not sufficient, but the overall watershed-health scores for the PDD and lower watersheds remained within their reference levels (approximately 0.5) (Fig. 9c and d). This waterquantity stress (large volume of water in the stream) may have negatively affected the water quality, with a decreased watershed-health score for the sediment, T-N, and T-P. In particular, the SYD watershed was rich in soil water and the CJD watershed was rich in surface and groundwater.
Figure 10 shows the changes in the watershed-health index score for the hydrologic and water-quality conditions during 1995-2004 and the most recent 10 years (2005-2014) based on the reference period (1985-1994). "Improved health", "deteriorating health", and "no change" in the Han River basin are illustrated with green, red, and white, respectively. The watershed's hydrologic condition was better in the North Han River basin compared to the South Han River basin. In particular, during the last 10 years (Fig. 10b), the watershed's health was poorer because of worse results for the surface process metric and soil water dynamics compared to those of the 1995-2004 period (Fig. 10a). However, during the last 10 years (Fig. 10d), the watershed's health increasingly improved in portions of the Han River basin compared to 19952004 (Fig. 10c), while the water quality of the Chungju Dam (CJD) watershed deteriorated. The water-quality policy of South Korea, which was developed after years of hard work and high costs, resulted in some improvements.

Figure 11 shows the poor watershed health in terms of the hydrology (Fig. 11a), water-quality (Fig. 11b), and overlay (Fig. 11c) results. The five poor levels for the hydrology and 

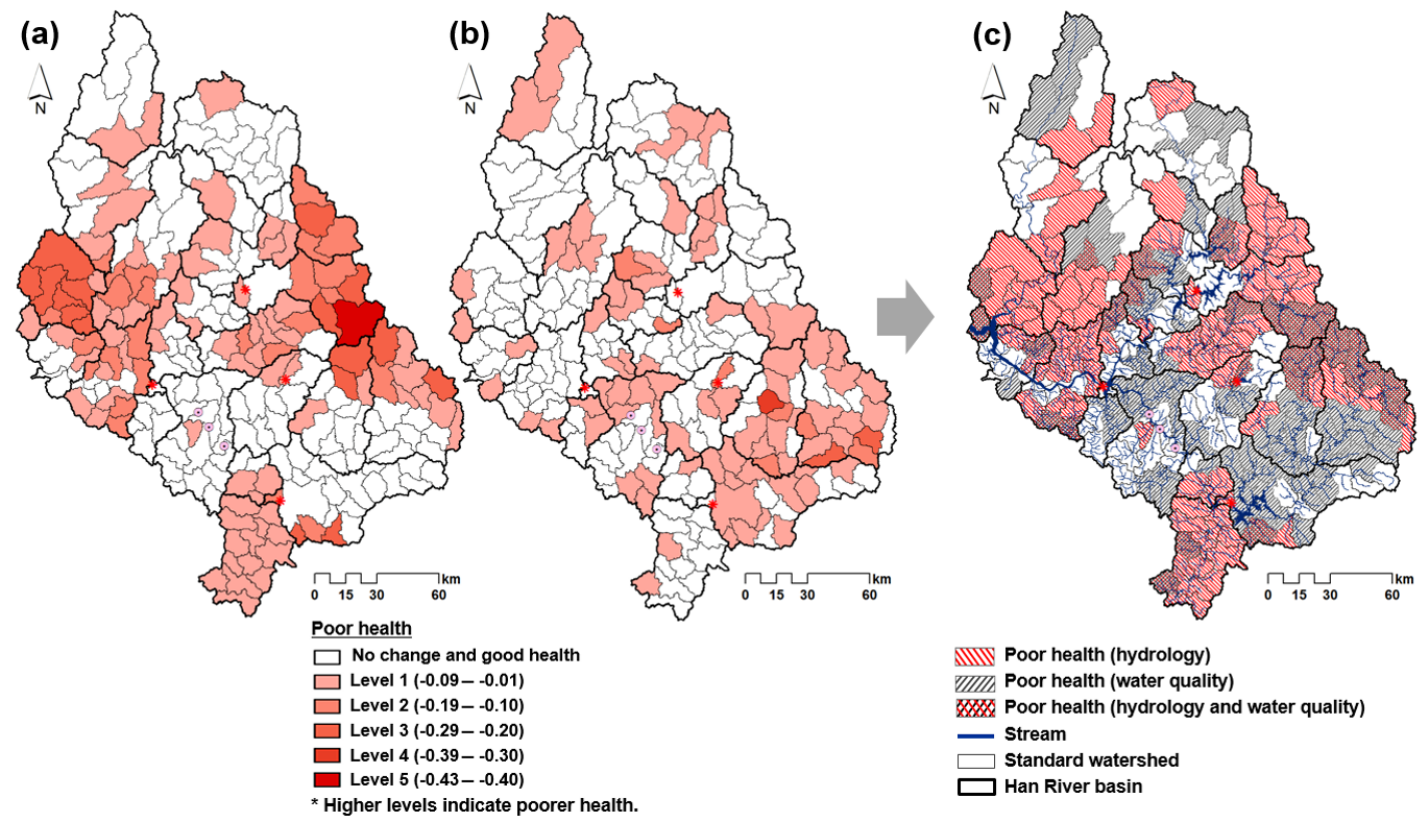

Figure 11. Poor watershed health as revealed by the (a) hydrology, (b) water-quality, and (c) overlay results.

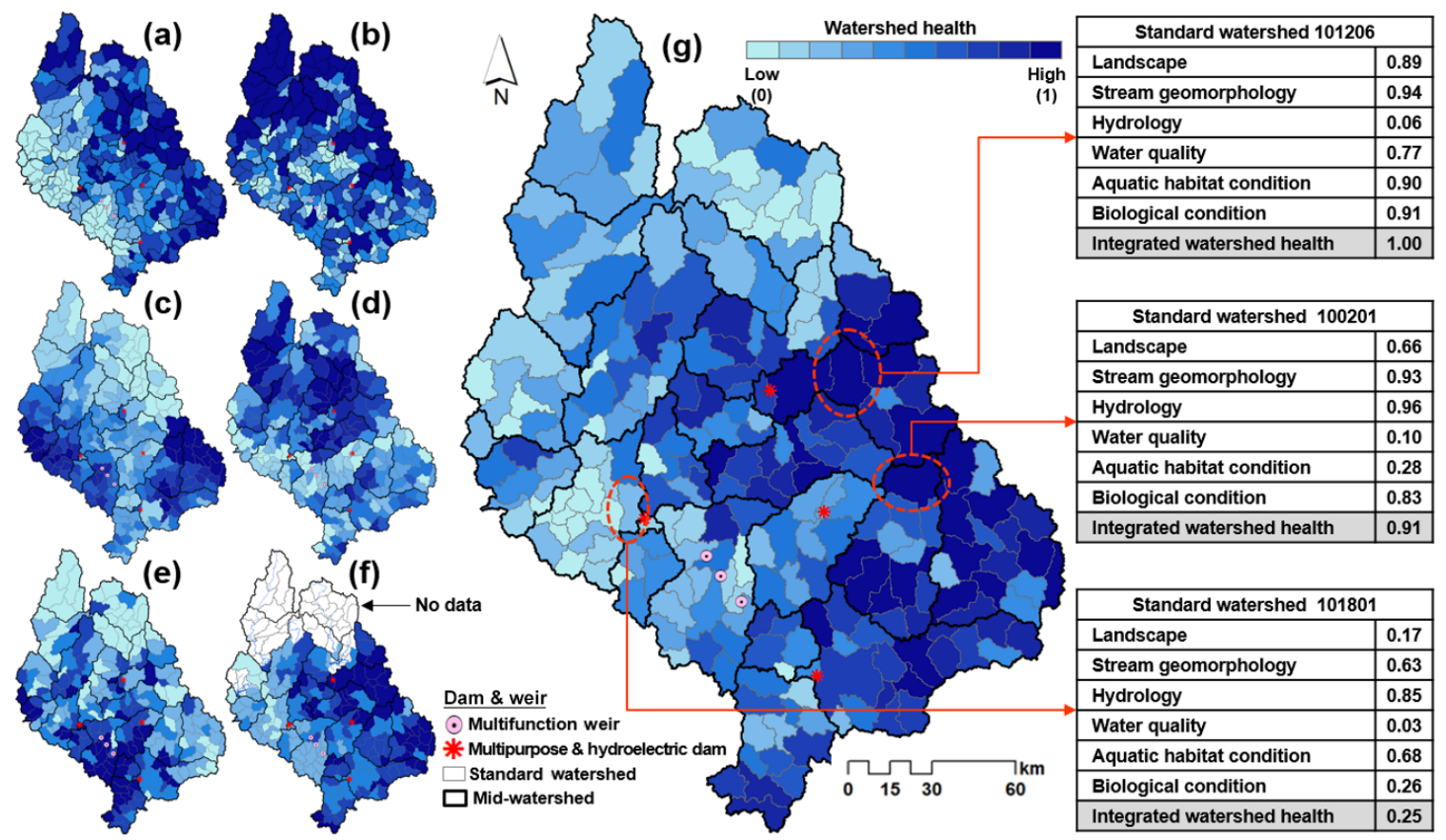

Figure 12. Watershed-health index results for the (a) landscape, (b) stream geomorphology, (c) hydrology, (d) water quality, (e) aquatic habitat, (f) biological condition, and (g) integrated watershed health.

water quality were calculated as the difference between panels (b) and (a) in Fig. 10 and between panels (d) and (c) in Fig. 10, respectively. The spatial distributions of the poor watershed-health levels enable us to understand the vulnerable areas in the CJD watershed, the upstream SYD water- shed, and the downstream PDD watershed with respect to the hydrology and water quality.

Figure 12e shows the sub-index scores for the watershedhealth assessment according to two assessment indicators (Fig. 7). The spatial-distribution patterns of the reservoirs for aquatic-habitat connectivity were concentrated in the down- 
Table 5. Watershed-health score results in each test area (upper/lower stream) of the Han River basin.

\begin{tabular}{|c|c|c|c|c|}
\hline Component & A (SYD watershed) & $\mathrm{B}$ (CJD watershed) & $\mathrm{C}$ (PDD watershed) & D (Lower watershed) \\
\hline Landscape & 0.80 & 0.66 & 0.53 & 0.26 \\
\hline Green infrastructure metric & 0.85 & 0.67 & 0.52 & 0.25 \\
\hline Active river area metric & 0.74 & 0.65 & 0.53 & 0.28 \\
\hline Geomorphology & 0.75 & 0.47 & 0.46 & 0.54 \\
\hline Hydrology & 0.21 & 0.74 & 0.37 & 0.60 \\
\hline Total & 0.19 & 0.51 & 0.44 & 0.65 \\
\hline Surface processes & 0.36 & 0.73 & 0.40 & 0.53 \\
\hline Soil water dynamics & 0.61 & 0.44 & 0.58 & 0.39 \\
\hline Groundwater dynamics & 0.30 & 0.55 & 0.45 & 0.58 \\
\hline Water quality & 0.63 & 0.45 & 0.52 & 0.48 \\
\hline Sediment & 0.40 & 0.29 & 0.55 & 0.61 \\
\hline $\mathrm{T}-\mathrm{N}$ & 0.76 & 0.70 & 0.49 & 0.32 \\
\hline T-P & 0.52 & 0.40 & 0.53 & 0.53 \\
\hline Aquatic habitat condition & 0.39 & 0.43 & 0.55 & 0.45 \\
\hline Habitat connectivity & 0.22 & 0.30 & 0.52 & 0.40 \\
\hline Wetland & 0.53 & 0.51 & 0.49 & 0.41 \\
\hline Biological condition & 0.92 & 0.73 & 0.47 & 0.23 \\
\hline TDI & 0.83 & 0.67 & 0.50 & 0.25 \\
\hline BMI & 0.88 & 0.78 & 0.46 & 0.22 \\
\hline FAI & 0.92 & 0.70 & 0.47 & 0.27 \\
\hline Integrated assessment & 0.82 & 0.75 & 0.47 & 0.30 \\
\hline
\end{tabular}

stream areas of the Han River basin. The spatial-distribution patterns of the wetlands seemed to follow a similar pattern. For the 101206 standard watershed, the normalized values of the aquatic-habitat connectivity and wetland were 0.00 (no reservoir) and 0.99 , respectively, and the sub-index score of 0.90 , which integrated the two normalized values, indicates a very healthy watershed. In contrast, the normalized values of the aquatic-habitat connectivity and wetland for the 100201 standard watershed were 0.46 and 0.34 , respectively, and the sub-index score of 0.28 , which integrated the two normalized values, indicates an unhealthy watershed. At the 101801 standard watershed, the aquatic-habitat condition results from the aquatic-habitat connectivity $(0.77)$ and wetland (0.66) indicators showed a relatively high value of 0.68 .

A sub-index analysis of the TDI, BMI, and FAI (Fig. 8) was conducted, except in the no-data areas (North Korea) in the Han River basin (Fig. 12f). The relationships of the TDI, BMI, and FAI were found to be significantly correlated. The TDI, BMI, and FAI were worse in the downstream areas. However, the degree to which the TDI, BMI, and FAI predict trophic diatom, benthic macroinvertebrate, and fish communities depends on the presence and levels of other stressors, such as large amounts of chlorophyll- $a$ (Chl- $a$ ), low dissolved oxygen (DO) and biochemical oxygen (BOD), and high temperature. The normalized values of the TDI, BMI, and FAI were 0.70, 0.98, and 0.92, respectively, in the 101206 standard watershed located upstream; 0.69,
0.98 , and 0.72, respectively, in the 100201 standard watershed located upstream; and $0.32,0.25$, and 0.25 , respectively, in the 101801 standard watershed located downstream. The sub-index scores after integrating the three normalized values were 0.91 and 0.83 for the 101206 and 100201 standard watersheds, respectively, indicating very healthy watersheds, and the sub-index score of 0.26 at the 101801 standard watershed indicated an unhealthy watershed.

The outputs of the watershed health provide basic data for local communities to proactively plan for growth. The sub-index results of the watershed-health assessment for each component can be optionally used to guide the masterplanning process for watershed management at the watershed scale depending on the specific management objectives and can be combined with any of the other sub-indices in the Han River basin to determine priority conservation areas.

\subsection{Assessment of the integrated watershed health}

To assess the overall watershed health in the Han River basin, the results of the individual assessments were synthesized to provide an integrated watershed-health index score for the 30-year period (1985-2014). The sample areas that were used to explain the differences in the watershed-health results for each component were the standard watersheds 101206 (urban $1.4 \%$ and forest $88.1 \%$ ), 100201 (urban $0.8 \%$ and forest $88.2 \%$ ), and 101801 (urban $9.8 \%$ and forest $55.7 \%$ ) 
(Fig. 2a). The 101 206, 100 201, and 101801 standard watersheds were located in the upstream region of the Soyang Dam (SYD), in the upstream region of the Chungju Dam (CJD), and in the downstream region of the Paldang Dam (PDD), respectively.

Figure 12 displays the normalized scores for each of the six attribute sub-indices and integrated watershed-health scores. The integrated watershed health exhibited a decreasing tendency farther down the watershed. The integrated watershed health of the 101206 and 100201 standard watersheds was revealed to be very good, with ratings of 1 and 0.91, respectively. However, the 101206 standard watershed exhibited a distinctive weakness with respect to the hydrologic condition (0.06), especially in the surface (0.16) and groundwater (0.17). Although the 100201 standard watershed was a very healthy watershed, similar to the 101206 watershed, the former showed a distinctive weakness with respect to the water quality $(0.1)$ and aquatic habitat condition (0.28). Systematic plans must be developed to suit watershed circumstances and characteristics so that watershed management is more effective. The 101801 watershed was revealed to be in poor health, with a water-quality rating of 0.25 . This area requires urgent action to restore the landscape, waterquality, and biological conditions and to protect the water quantity. Table 5 shows the watershed-health scores in the test areas (upper/lower stream) of the Han River basin.

\section{Conclusions}

In this study, a watershed-health assessment of the Han River basin in South Korea was performed by using monitoring data and SWAT modeling results. Six essential indicators of healthy watersheds were used in the assessment: (1) the landscape condition, (2) geomorphology, (3) hydrology, (4) water quality, (5) habitat, and (6) biological condition. In particular, a sub-index of the watershed health that was related to the hydrology and water quality was developed to assess possible long-term changes in the watershed by using SWAT modeling results.

During the most recent 10-year period (2005-2014), the watershed's health declined, as indicated by the worse results for the surface process metric and soil water dynamics compared to those of the 1995-2004 period. The spatial distributions of the poor watershed-health levels revealed vulnerable areas in portions of the CJD watershed, upstream SYD watershed, and downstream PDD watershed with respect to the hydrology and water quality.

The sub-index results of the watershed-health assessment for each component can be used to guide the master-planning process for watershed management at the watershed scale based on specific management objectives and can be combined with any of the other sub-indices in the Han River basin to determine priority conservation areas. Listing all the information of the watershed-health assessment can in- dicate vulnerable or healthy regions in the desired area and can provide basic data for action. The effectiveness of the watershed-health evaluation in this study can produce reliable information because this approach is entirely physically based. This approach can be utilized in a number of standard watersheds, local communities, and regions throughout the Han River basin and can be practically implemented in the watershed as a comprehensive watershed-management plan by government authorities or representative stakeholders.

Finally, the limitations of this study include the simulation of water quantity and quality data for possible long-term changes in the watershed model. Although the prediction of long-term water quantity and quality data with this modeling is essential to assess water-resource systems, the hydrologic and water-quality conditions cannot be perfectly projected because of uncertainties in the models, climate data, and other inputs that are required for the simulations. However, the results of this study are useful in terms of identifying potential watershed-health issues that are associated with ongoing watershed changes.

Data availability. Data for this paper can be found in the Supplement.

\section{The Supplement related to this article is available online at https://doi.org/10.5194/hess-21-5583-2017- supplement.}

Competing interests. The authors declare that they have no conflict of interest.

Special issue statement. This article is part of the special issue "Coupled terrestrial-aquatic approaches to watershed-scale water resource sustainability". It is not associated with a conference.

Acknowledgements. This research was supported by a grant (14AWMP-B082564-01) from the Advanced Water Management Research Program funded by the Ministry of Land, Infrastructure and Transport of the Korean government.

Edited by: Xuesong Zhang

Reviewed by: Tian Guo and one anonymous referee

\section{References}

Ahn, S. R. and Kim, S. J.: Assessment of climate change impacts on the future hydrologic cycle of the Han River Basin in South Korea using a grid-based distributed model, Irrig. Drain., 65, 1121, https://doi.org/10.1002/ird.1963, 2016.

Ahn, S. R., Jeong, J. H., and Kim, S. J.: Assessing drought threats to agricultural water supplies under climate change by 
combining the SWAT and MODSIM models for the Geum River basin, South Korea, Hydrolog. Sci. J., 61, 2740-2753, https://doi.org/10.1080/02626667.2015.1112905, 2016.

Arnold, J. G., Srinivasan, R., Muttiah, R. S., and Williams, J. R.: Large area hydrologic modeling and assessment part I: Model development, J. Am. Water Resour. As., 34, 73-89, https://doi.org/10.1111/j.1752-1688.1998.tb05961.x, 1998.

Blazkova, S., Beven, K., Tacheci, P., and Kulasova, A.: Testing the distributed water table predictions of TOPMODEL (allowing for uncertainty in model calibration): the death of TOPMODEL?, Water Resour. Res., 38, 39-31, https://doi.org/10.1029/2001WR000912, 2002.

Bouraoui, F., Grizzetti, B., Granlund, K., Rekolainen, S., and Bidoglio, G.: Impact of climate change on the water cycle and nutrient losses in a Finnish catchment, Climatic Change, 66, 109-126, https://doi.org/10.1023/B:CLIM.0000043147.09365.e3, 2004.

Cameron, D., Beven, K., and Naden, P.: Flood frequency estimation by continuous simulation under climate change (with uncertainty), Hydrol. Earth Syst. Sci., 4, 393-405, https://doi.org/10.5194/hess-4-393-2000, 2000.

Chang, H.: Spatial analysis of water quality trends in the Han River basin, South Korea, Water Res., 42, 3285-3304, https://doi.org/10.1016/j.watres.2008.04.006, 2008.

Chaplot, V.: Water and soil resources response to rising levels of atmospheric $\mathrm{CO}_{2}$ concentration and to changes in precipitation and air temperature, J. Hydrol., 337, 159-171, https://doi.org/10.1016/j.jhydrol.2007.01.026, 2007.

Chung, E. S., Abdulai, P. J., Park, H., Kim, Y., Ahn, S. R., and Kim, S. J.: Multi-criteria assessment of spatial robust water resource vulnerability using the TOPSIS method coupled with objective and subjective weights in the Han River basin, Sustainability, 9, 29, https://doi.org/10.3390/su9010029, 2017.

Cook, N. A., Sarver, E. A., Krometis, L. H., and Huang, J.: Habitat and water quality as drivers of ecological system health in central Appalachia, Ecol. Eng., 84, 180-189, https://doi.org/10.1016/j.ecoleng.2015.09.006, 2015.

Eckhardt, K. and Ulbrich, U.: Potential impacts of climate change on groundwater recharge and streamflow in a central European low mountain range, J. Hydrol., 284, 244-252, https://doi.org/10.1016/j.jhydrol.2003.08.005, 2003.

Freer, J., Beven, K., and Ambroise, B.: Bayesian estimation of uncertainty in runoff prediction and the value of data: an application of the GLUE approach, Water Resour. Res., 32, 2161-2173, https://doi.org/10.1029/95WR03723, 1996.

Gupta, H. V., Beven, K. J., and Wagener, T.: Model calibration and uncertainty estimation, in: Encyclopedia of Hydrological Sciences, edited by: Anderson, M. G., John Wiley, New York, 20152031, 2005.

IPCC: Climate Change 2007: The Physical Science Basis. Contribution of Working Group I to the Fourth Assessment Report of the Intergovernmental Panel on Climate Change, edited by: Solomon, S., Qin, D., Manning, M., Chen, Z., Marquis, M., Averyt, K. B., Tignor, M., and Miller, H. L., Cambridge University Press, Cambridge, 2007.

Jun, K. S., Chung, E. S., Sung, J. Y., and Lee, K. S.: Development of spatial water resources vulnerability index considering climate change impacts, Sci. Total Environ., 409, 5228-5242, https://doi.org/10.1016/j.scitotenv.2011.08.027, 2011.
Karlsson, I. B., Sonnenborg, T. O., Refsgaard, J. C., Trolle, D., Børgesen, C. D., Olesen, J. E., Jeppesen, E., and Jensen, K. H.: Combined effects of climate models, hydrological model structures and land use scenarios on hydrological impacts of climate change, J. Hydrol., 535, 301-317, https://doi.org/10.1016/j.jhydrol.2016.01.069, 2016.

Kim, S., Kim, B. S., Jun, H., and Kim, H. S.: Assessment of future water resources and water scarcity considering the factors of climate change and social-environmental change in Han River basin, Korea, Stoch. Env. Res. Risk A., 28, 1999-2014, https://doi.org/10.1007/s00477-014-0924-1, 2014.

King, R. S., Baker, M. E., Kazyak, P. F., and Weller, D. E.: How novel is too novel? Stream community thresholds at exceptionally low levels of catchment urbanization, Ecol. Appl., 21, 16591678, 2011.

Kline, M., Alexander, C., Pytlik, S., Jaquith, S., and Pomeroy, S.: Vermont Stream Geomorphic Assessment Protocol Handbooks and Appendices, Vermont Agency of Natural Resources, Waterbury, VT, 2009.

Mehdi, B., Ludwig, R., and Lehner, B.: Evaluating the impacts of climate change and crop land use change on streamflow, nitrates and phosphorus: A modeling study in Bavaria, J. Hydrol., 4, 6090, https://doi.org/10.1016/j.ejrh.2015.04.009, 2015.

Ministry of Environment: Nationwide Aquatic Ecological Monitoring Program, National Institute of Environmental Research, Incheon, South Korea, 2013.

Minnesota Department of Natural Resources: Watershed Assessment Tool, available at: http://www.dnr.state.mn.us/watershed_ tool/index.html, last access: 29 November 2011.

Moriasi, D. N., Arnold, J. G., Van Liew, M. W., Bingner, R. L., Harmel, R. D., and Veith, T. L.: Model evaluation guidelines for systematic quantification of accuracy in watershed simulations, T. ASABE, 50, 885-900, https://doi.org/10.13031/2013.23153, 2007.

Neitsch, S. L., Arnold, J. G., Kiniry, J. R., and Williams, J. R.: Soil and Water Assessment Tool Theoretical Documentation, Version 2000, USDA-ARS Grassland, Soil, and Water Research Laboratory, Blackland Research Center, Temple, TX, 2002.

Neitsch, S. L., Arnold, J. G., Kiniry, J. R., Williams, J. R., and King, K. W.: Soil and Water Assessment Tool Theoretical Documentation, Version 2005, Agricultural Research Service and the Texas Agricultural Experiment Station, Temple, TX, 2005.

Randall, G. W. and Mulla, D. J.: Nitrate nitrogen in surface waters as influenced by climatic conditions and agricultural practices, J. Environ. Qual., 30, 337-344, https://doi.org/10.2134/jeq2001.302337x, 2001.

Rosenberg, N. J., Brown, R. A., Izaurralde, R. C., and Thomson, A. M.: Integrated assessment of Hadley centre (HadCM2) climate change projections on agricultural productivity and irrigation water supply in the conterminous United States, Agr. Forest Meteorol., 117, 73-96, https://doi.org/10.1016/S0168-1923(03)00025$\mathrm{X}, 2003$.

Sanchez, G. M., Nejadhashemi, A. P., Zhang, Z., Marquart-Pyatt, S., Habron, G., and Shortridge, A.: Linking watershed-scale stream health and socioeconomic indicators with spatial clustering and structural equation modeling, Environ. Modell. Softw., 70, 113-127, https://doi.org/10.1016/j.envsoft.2015.04.012, 2015 . 
Santhi, C., Arnold, J. G., Williams, J. R., Dugas, W. A., Srinivasan, R., and Hauck, L. M.: Validation of the SWAT model on a large river basin with point and nonpoint sources, J. Am. Water Resour. As., 37, 1169-1188, https://doi.org/10.1111/j.17521688.2001.tb03630.x, 2001.

Sellami, H., Benabdallah, S., La Jeunesse, I., and Vanclooster, M.: Quantifying hydrological responses of small Mediterranean catchments under climate change projections, Sci. Total Environ., 543, 924-936, https://doi.org/10.1016/j.scitotenv.2015.07.006, 2016.

Shilling, F.: California watershed assessment Manual, University of California, Davis, available at: http://cwam.ucdavis.edu (last access: 13 June 2009), 2007.

Smith, E., Tran, L., and O'Neill, R.: Regional Vulnerability Assessment for the Mid-Atlantic Region: Evaluation of Integration Methods and Assessments Results, Environmental Protection Agency, U.S., Washington D.C., 2003.

Sun, H. and Cornish, P. S.: Estimating shallow groundwater recharge in the headwaters of the Liverpool plains using SWAT, Hydrol. Process., 19, 795-807, https://doi.org/10.1002/hyp.5617, 2005.

Tango, P. J. and Batiuk, R. A.: Chesapeake Bay recovery and factors affecting trends: long-term monitoring, indicators, and insights, Reg. Stud. Mar. Sci., 4, 12-20, https://doi.org/10.1016/j.rsma.2015.11.010, 2016.

USDA-SCS: Hydrology. Section 4, in: National Engineering Handbook, edited by: Vache, K. B., U.S. Department of Agriculture, Soil Conservation Service, Washington D.C., 1972.
U.S. EPA: National Lakes Assessment: A Collaborative Survey of the Nation's Lakes, EPA, 841-R-09-001, U.S. Environmental Protection Agency, Office of Water and Office of Research and Development, Washington D.C., 2009.

U.S. EPA: Identifying and Protecting Healthy Watersheds: Concepts, Assessments, and Management Approaches, EPA, 841-B11-002, U.S. Environmental Protection Agency, Office of Water and Office of Research and Development, Washington D.C., 2012.

Virginia Department of Conservation and Recreation: Virginia Conservation Lands Needs Assessment, Natural Heritage, available at: http://www.dcr.virginia.gov/natural_heritage/vclna. shtml (last access: 27 April 2009), 2008.

Wan, R., Liu, D., Munroe, D. K., and Cai, S.: Modelling potential hydrological impact of abandoned underground mines in the Monday Creek watershed, Ohio, Hydrol. Process., 27, 36073616, https://doi.org/10.1002/hyp.9476, 2013.

Wang, X. and Yin, Z.: Using GIS to assess the relationship between land use and water quality at a watershed level, Environ. Int., 23, 103-114, https://doi.org/10.1016/S0160-4120(96)00081-5, 1997.

Watershed Professionals Network: Oregon Watershed Assessment Manual, Governor's Watershed Enhancement Board, Salem and Publishing House, Oregon, 1999.

Zhou, Z. X. and Li, J.: The correlation analysis on the landscape pattern index and hydrological processes in the Yanhe watershed, China, J. Hydrol., 524, 417-426, https://doi.org/10.1016/j.jhydrol.2015.02.028, 2015. 